Florida International University

FIU Digital Commons

FIU Electronic Theses and Dissertations

University Graduate School

3-26-1997

\title{
An investigation of the relationships among self- care behaviors, health beliefs, and metabolic control in the non-insulin-dependent diabetic adult
}

Sonia R. Anglin

Florida International University

DOI: $10.25148 /$ etd.FI14032322

Follow this and additional works at: https://digitalcommons.fiu.edu/etd

Part of the Nursing Commons

\section{Recommended Citation}

Anglin, Sonia R., "An investigation of the relationships among self-care behaviors, health beliefs, and metabolic control in the noninsulin-dependent diabetic adult" (1997). FIU Electronic Theses and Dissertations. 1419.

https://digitalcommons.fiu.edu/etd/1419 
FLORIDA INTERNATIONAL UNIVERSITY

Miami, Florida

AN INVESTIGATION OF THE RELATIONSHIPS AMONG SELF-CARE BEHAVIORS, HEALTH BELIEFS, AND METABOLIC CONTROL IN THE NONINSULIN-DEPENDENT DIABETIC ADULT.

A thesis submitted in partial satisfaction of the requirements for the degree of MASTER OF SCIENCE

IN

NURSING

by

Sonia R. Anglin 


\section{To: Dean Linda Simunek}

School of Nursing

This thesis, written by Sonia R. Anglin, and entitled "An investigation of the relationships among self-care behaviors, health beliefs, and metabolic control in the non-insulin-dependent diabetic adult", having been approved in respect to style and intellectual content, is referred to you for judgement.

We have read this thesis and recommend that it be approved.

Lourdes Lizardo

Jay Sosenko

Divina Grossman, Major Professor

Date of Defense: March 26, 1997

The thesis of Sonia R. Anglin is approved.

Dean Linda Simunek

School of Nursing $A$

Dr. Richard Campbell

Dean of Graduate Studies

Florida International University, 1997 


\section{ACKNOWLEDGMENTS}

I would like to thank the members of my committee for their patience and

guidance during this endeavor. Special thanks to Dr. Barbara Kearney and Dr. Barbara Fleischer for permission to use the Exercise of Self-care Agency Instrument, and to Dr. Charles Givens for the use of the Diabetic Patients' Health Beliefs Scales.

I am especially grateful to my family and friends for their encouragement throughout the process. This thesis would not have been possible without my friends Aida and Ken Gall, Mary Mites and Patricia Calhoun who never failed in giving their support, and who listened and encouraged when I was discouraged and needed to talk. My heartfelt appreciation also goes to Aida Gall, Alina Gonzalez, Maricela Rodriguez, Marie Rosiclair and Anna Pierre who undertook the formidable task of translating the consent forms and the questionnaires into Spanish and Creole.

Finally, and most important, I thank God for giving me the health, stamina and ability to complete this project. 


\section{ABSTRACT OF THE THESIS \\ AN INVESTIGATION OF THE RELATIONSHIPS AMONG SELF-CARE \\ BEHAVIORS, HEALTH BELIEFS, AND METABOLIC CONTROL IN THE NON- \\ INSULIN-DEPENDENT DIABETIC ADULT}

by

Sonia R. Anglin

Florida International University, 1997

Miami, Florida

\section{Professor Divina Grossman, Major Professor}

Self-care and health beliefs have been found to be important concepts in the management of chronic diseases such as diabetes mellitus. Poor metabolic control has been associated with a higher incidence of complications in diabetic patients. This study sought to explore any relationships among perceptions of self-care behaviors, health beliefs and metabolic control.

The sample consisted of 52 outpatients with non-insulin-dependent diabetes from a large teaching medical center. Interviews were done to obtain the patients' perceptions of their self-care behaviors, and their health beliefs concerning diabetes. Results of glycosylated hemoglobin and/or serum glucose levels were obtained from the medical records. Data were analyzed using Cochran-Mantel-Haenzel statistics, and Pearson's $r$. 
Results indicated no significant relationships among perceptions of selfcare behaviors, health beliefs and metabolic control. Ethnicity, education and gender were found to be significantly associated with self-care behaviors and health beliefs. 


\section{TABLE OF CONTENTS}

CHAPTER

PAGE

I. INTRODUCTION $\ldots \ldots \ldots \ldots \ldots \ldots \ldots \ldots \ldots \ldots \ldots \ldots \ldots \ldots \ldots \ldots$

Research Purpose $\ldots \ldots \ldots \ldots \ldots \ldots \ldots \ldots \ldots \ldots$

Specific Research Questions ................ 4

Operational Definitions.$\ldots \ldots \ldots \ldots \ldots \ldots \ldots \ldots \ldots$

Variables Under Study $\ldots \ldots \ldots \ldots \ldots \ldots \ldots \ldots \ldots, 6$

Significance of the Study $\ldots \ldots \ldots \ldots \ldots \ldots \ldots \ldots \ldots$

II. REVIEW OF THE LITERATURE $\ldots \ldots \ldots \ldots \ldots \ldots \ldots \ldots \ldots \ldots$

Definitions of Self-care $\ldots \ldots \ldots \ldots \ldots \ldots \ldots \ldots$

Self-Care and Chronic Illness ................. 10

Self-Care and Education $. \ldots \ldots \ldots \ldots \ldots \ldots \ldots \ldots, 13$

Self-Care and Health Beliefs $\ldots \ldots \ldots \ldots \ldots \ldots \ldots \ldots \ldots$

Self-Care and Compliance $\ldots \ldots \ldots \ldots \ldots \ldots \ldots \ldots .17$

Self-care and Diabetic Complications ............. 18

Conceptual Framework ................... 19

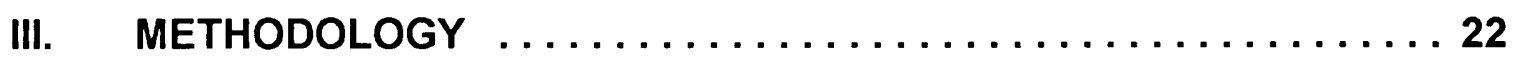

Study Design $\ldots \ldots \ldots \ldots \ldots \ldots \ldots \ldots \ldots \ldots \ldots \ldots \ldots \ldots 22$

Population Characteristics and Setting $\ldots \ldots \ldots \ldots \ldots 22$

Sampling $\ldots \ldots \ldots \ldots \ldots \ldots \ldots \ldots \ldots \ldots \ldots \ldots \ldots \ldots \ldots$

Data Collection Instruments . . . . . . . . . . . 23 
Data Collection Procedures . . . . . . . . . . . . 25

Methods of Data Analysis . . . . . . . . . . . 26

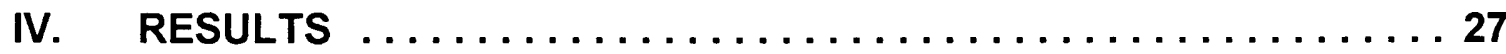

Sample Characteristics ................. 27

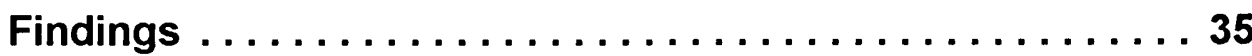

V. DISCUSSION AND CONCLUSIONS $\ldots \ldots \ldots \ldots \ldots \ldots \ldots \ldots . \ldots$

Discussion of Findings. . . . . . . . . . . . . 49

Limitations $\ldots \ldots \ldots \ldots \ldots \ldots \ldots \ldots \ldots \ldots \ldots \ldots \ldots$

Recommendations for Future Research .......... 55

Nursing Implications $\ldots \ldots \ldots \ldots \ldots \ldots \ldots \ldots \ldots$

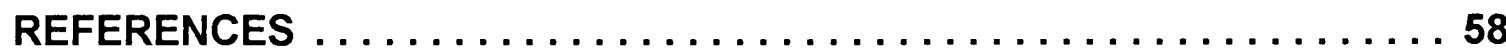

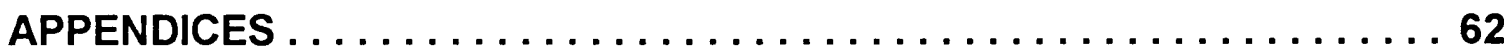

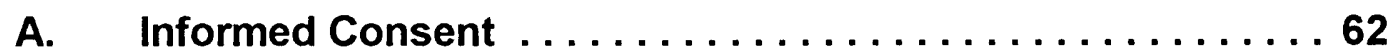

B. Exercise of Self-Care Agency Scale $\ldots \ldots \ldots \ldots \ldots \ldots 73$

C. Diabetic Patients' Health Beliefs Scales $\ldots \ldots \ldots \ldots \ldots$. . 82

D. Demographic Data Sheet $\ldots \ldots \ldots \ldots \ldots \ldots \ldots \ldots \ldots$

E. Metabolic Control Profile-- Data Collection Sheet . . . . . . 97

F. Permissions. $\ldots \ldots \ldots \ldots \ldots \ldots \ldots \ldots \ldots \ldots \ldots$ 98 


\section{LIST OF TABLES}

TABLE

PAGE

1. Sociodemographic Characteristics of the Sample. . . . . . . . . . 29

2. Glycosylated Hemoglobin Values. . . . . . . . . . . . 33

3. Serum Fasting Glucose Values. . . . . . . . . . . . . . . . 34

4. Subjects' Scale Means for the ESCA. . . . . . . . . . . . 38

5. Mean Scores for the Diabetics' Health Beliefs Scales. . . . . . . . . 41

6. Intercorrelations Between Subconstructs of the ESCA. . . . . 43

7. Intercorrelations Between The Health Beliefs' Scales. . . . . . . . . 44 


\section{Chapter 1}

\section{Introduction}

A significant number of people in our society are afflicted with chronic diseases such as diabetes, hypertension, asthma, other chronic obstructive pulmonary diseases, and arthritis. According to Wilson and Sharma (1995), "nearly three percent of the United States (U.S.) has diabetes mellitus" (p.249). In patients with diabetes, there is a high cost associated with the disease due to tolls on the quality of life, and from complications requiring hospitalizations. Cost is an important area of concern in health care. Tertiary institutions in particular, account for a large part of health care expenditures. Wilson and Sharma (1995) stated,

The expense of hospitalization accounted for 40.5 percent of the total economic cost of diabetes mellitus in 1992. The direct cost for hospitalization due to diabetes was 3.9 billion dollars, while that of complications of diabetes was 9.7 billion dollars. (p.249).

The growing trend is to reduce costs as much as possible and as a result, there is a great deal of emphasis on primary care and home health care today. This places tremendous importance on patients and their families participating in levels of care that were previously unknown to them. Over the last decade, home health care has expanded to include many of the procedures and 
therapies that were previously done only in the hospital such as placement of peripherally inserted central lines, portable $\mathrm{x}$-rays and hyperalimentation therapy. In referring to self-care and home care management, Anderson (1990) stated that "... fiscal matters have been a major impetus for pursuing these directions in health care delivery." (p. 72).

Patient and family participation in the treatment of their diseases is critical to the restoration of high-level wellness. A partnership between the health care practitioner and the patient is essential especially in the treatment of chronic diseases. Corbin and Strauss (1991), in formulating a nursing model for chronic illness management, observed that very little of the management of chronic illness took place in hospitals or other health care facilities. Rather, most took place in the home. Health care providers, therefore, must take the time to find out how their clients deal with their chronic illnesses, and utilize this knowledge to formulate plans to deliver comprehensive care. The expected outcomes of these actions are patients who are empowered to direct their own care, and also a decrease in the number of preventable "crisis situations" which may result in hospital admissions.

Hays, Kravitz, Mazel, Sherbourne, DiMatteo, Rogers \& Greenfield (1994) reported on the Medical Outcomes Study, which was a four-year observational study that examined "the influence of specific characteristics of providers, patients, and health systems on outcomes of care." (p.348). Subjects in this 
study had one or more of the medical conditions of diabetes, hypertension, congestive heart failure, recent myocardial infarction, and/or depressive symptoms. They concluded that "the relationship between adherence and health outcomes is much more complex than has often been assumed." ( p.348). Despite the absence of a consistent relationship between adherence and outcomes, their results suggested that "better adherence (especially to diet) was associated with improved health outcomes among insulin-using diabetics but not among patients with other chronic conditions." ( p. 355). This result was consistent with other studies previously conducted by these researchers. They also concluded that adherence to therapy was an especially important factor in patients with chronic diseases "...because so much of the course of the illness depends on self-care behaviors." (p.355).

According to the American Diabetes Association (1995), in non-insulindependent diabetic patients, "considerable evidence exists for a relationship between microvascular disease and hyperglycemia similar to that proven for IDDM" (p.9). The desired outcome of treatment in diabetes is to lower glucose levels and prevent or ameliorate acute and long-term complications. To achieve this goal, it is imperative that the patient engages in self-care behaviors such as diet adherence, exercise, weight reduction and adherence to hypoglycemic agents as ordered. The patient's health belief systems may influence to a large extent which self-care behaviors the patient will actually practice. These beliefs 
include the patient's perceptions of how they perform self-care. It is therefore important to the health care provider to identify these beliefs, perceptions and behaviors, and to consider them when planning or performing care for each patient.

\section{Research Purpose}

The purpose of this study was twofold:

(1) to examine the relationships among self-care perceptions, health beliefs, and the degree of metabolic control in non-insulin-dependent diabetic adults (NIDDA); and

(2) to describe the influence of socio-demographic factors (age, ethnicity, gender, education) on health beliefs and self-care perceptions.

\section{Specific Research Questions}

The specific research questions were as follows:

1) What are common perceptions of self-care behaviors in non-insulindependent diabetic adults?

2) What are some health beliefs of non-insulin-dependent diabetic adults?

3) To what extent do the health beliefs and self-care behaviors of these patients relate to their level of metabolic control?

4) To what extent does age or ethnicity or gender or education influence self-care perceptions and health beliefs? 
Operational definitions

Self-care perceptions refer to the patients' beliefs and feelings about their performance of actions to improve or maintain stability of their diabetic state. This was assessed using the Exercise of Self-Care Agency Instrument (Kearney and Fleischer, 1979 ).

Non-insulin-dependent diabetic patients are adults, 35 years and older, who have been diagnosed with Type II diabetes mellitus, and are being treated by diet and/or hypoglycemic agents (oral or insulin). Diagnosis of Type II diabetes mellitus was identified from review of the medical records of the subjects.

Health beliefs are defined as the patient's perception of the severity of the disease process, perception of the benefits of adherence to treatment, and perceptions of barriers to control of the disease. This was measured using the Health Beliefs of Diabetic Patients' Scales (Given, Given, Gallin \& Condon 1983).

Metabolic control is defined as the level of glucose in the blood as measured by glycosylated hemoglobin levels and/or serum fasting glucose levels.

Metabolic Control

$\begin{array}{lllll} & \text { Good } & \text { Acceptable } & \text { Poor } & \text { Very Poor } \\ \text { Glycosylated Hemoglobin } & \leq 6 \% & 6.1-7 \% & 7.1-10 \% & \geq 10 \% \\ \text { Serum Fasting Glucose } & <115 & >115<140 & >140<200 & >200\end{array}$




\section{Variables under Study}

The variables were self-care perceptions, health beliefs, metabolic control, and socio-demographic factors.

Significance of the study

Several researchers have found that patients with diabetes have a higher rate of hospital admissions and more inpatient days than non-diabetic patients. (Nordberg, Chalew, Barlow and McCarter, 1993; Aro, Kangas, Reunanen, Salinto, and Koivisto, 1994; Wilson and Sharma, 1995). In addition to the general costs to society, the patient also suffers because of disruption to his or her lifestyle and loss of productive hours from work. The elderly age group (age 65 or older) has been identified as especially vulnerable to complications of diabetes and therefore increased hospitalizations. (Aro, Kangas, Reunanen, Salinto, and Koivisto, 1994). Some other risk factors for high rates of hospitalization which were identified by other researchers include lack of insurance and decreased access to care. (Nordberg, Chalew, Barlow and McCarter, 1993; Wilson and Sharma, 1995). Despite these potential risks, some diabetic patients are able to maintain themselves fairly well in their home environment. Pollock (1989) researched adaptive responses in patients with insulin-dependent diabetes mellitus and stated, management of insulin-dependent diabetes mellitus (IDDM) is complex and requires the patient's daily awareness of and attention to the 
condition... While diabetes is a stressful chronic illness and not curable at present, control of the disease is an achievable goal for many. (p.265). A similar level of self-care and goal can be set for patients with non-insulindependent diabetes.

Corbin and Strauss (1991) developed a model for chronic illness management based upon a trajectory framework. In this model, there are several stages: 1) pre-trajectory, 2) trajectory onset, 3) crisis, 4) acute, 5) stable, 6) unstable, 7) downward, and 8) dying. The acute stage is the stage of active illness or complications that require hospitalization and the stable phase is where illness course/symptoms are controlled by the prescribed regimen. In diabetes, it is important to identify those behaviors that are necessary for the patient to remain in the stable phase of the chronic illness trajectory rather than the acute phase where hospitalization is required. It has been established that those clients with consistently high levels of glucose in the serum are at an increased risk for the complications of diabetes and their sequelae. It is therefore important to be able to identify those patients who are at increased risk for complications, so that they can be targeted for intervention and possible prevention of those complications. Client assessment, diagnosis, treatment and education are directed toward accomplishing these goals. Management of these domains is directed through the use of nursing and medical research such as this study. The patient's beliefs and attitudes are of central importance in any 
treatment regime, but especially so in the treatment of chronic diseases.

Knowledge of these beliefs and attitudes and how they affect the patient's wellbeing is necessary for the health care practitioner to be able to enhance the care given, and to plan with the patient the best method by which such care can be delivered. Hence, this study was conducted to identify the extent to which the variables of self-care perceptions, health beliefs and socio-demographic factors affect the metabolic stability of the non insulin-dependent diabetic patient. The results will contribute to the body of professional nursing knowledge by identification of some of the mechanisms which may have a significant role in client outcomes. It is also expected that the information will make practitioners more aware of the meaning and significance of diabetes to patients and their quality of life. Interventions such as education programs and therapeutic regimes can be influenced by this knowledge. 


\section{Chapter 2}

\section{Review of the literature}

The presence of a chronic disease in a patient involves the rendering of continual care to the patient. Generally, in situations where patients are able to, they become the primary provider of this care, i.e., self-care agency. Other providers of care may include family members, friends and health care personnel. Orem (1980) states, "both self-help and help to others are valued by society as desirable activities" (p.6). Self-care, or the provision of care by others, has as its objective to maintain or regain integrity of the health of the individual. Healthy individuals are valuable to society, since they are generally expected to be more productive, and make fewer demands on health care resources. Definitions of self-care

Keller, Ward \& Baumann (1989) defined self-care as "...the range of activities that individuals personally initiate and perform on their own behalf to maintain life, health, and well-being." (p. 54). This implies continual and purposeful actions to accomplish and maintain a certain acceptable state of living (health) to the patient. According to Chinn and Kramer (1991), "well-being refers to a person's perceived condition of existence, which is characterized by experiences of contentment, pleasure, happiness, movement toward self-ideals, and continuing personalization" (p.183). 
Levin (as cited in Dodd, 1988) stated, "self-care means practicing selfobservation, recognizing and labeling symptoms, judging their severity, and assessing and choosing treatment options" (p.7). Fitzpatrick and Whall (1989) defined self-care in the following way: "the production of actions directed to self or environment to regulate human structure, function, and integrity." All these definitions emphasize that self-care encompasses deliberate decisions and actions which affect the person's health.

Self-Care and chronic illness

The importance of self-care in chronic disease has been addressed by several researchers. Germain and Nemchik (1988) investigated the desire of diabetic patients to maintain self-care activities during hospitalization. The subjects used were members of a chapter of the American Diabetic Association and were a fairly well educated group with at least a high school education. More than $50 \%$ also self reported compliance with their doctors' orders most of the time. Content validity was established by the use of a panel of experts. A pilot study was also done. The patients were questioned about self-care during any past hospitalization as well as their expectations for any potential hospitalization. Most subjects expressed the desire to continue their self-care while in the hospital. The researchers found that there was some incongruence with this expressed desire and the actual participation in self-care practices of patients who had been hospitalized, since in most cases care was performed by 
the hospital staff. No explanations were proposed for this observation.

The data analysis showed no significant relationships between daily selfcare habits at home and beliefs about self-care in the hospital; daily self-care in the hospital and the type of diabetes; or in beliefs about continuing self-care in the hospital and type of diabetes. There was also no significant relationship between the occurrence of hospitalization since diagnosis and daily self-care habits at home. This study is limited in its generalizability because of the small sample size and because patients who are members of the American Diabetes Association may not necessarily be reflective of the general population of patients with diabetes. However, the study did indicate that self-management behaviors may be important to diabetic patients even when they require hospitalization. No statistically significant relationship was found between home self-care and hospitalization in this study. Despite this, the findings that patients expressed the desire to continue self-care activities should not be ignored. Further studies are needed and could yield differing results. Evaluation of the level of participation desired by patients should be assessed since patients have differing expectations on how much of their own care they wish to actually perform while in the hospital.

Another study by Connelly (1993) examined the efficiency of a model of self-care in chronic illness. The method used was a descriptive correlational study of the variables influencing self-care. The study was conducted on 
chronically ill patients of an ambulatory care clinic in a military medical center.

Many of the patients had more than one of four diagnoses: arthritis, hypertension, heart disease and diabetes. Items on the questionnaire measured the areas of self-concept, psychological status, and social support. Validity and reliability were established. The results indicated a high rate of therapeutic selfcare behaviors. Ninety one percent of the subjects reported taking their medications as prescribed most of the time, and $86 \%$ stuck to their diets most of the time. There was no correlation among the three types of self-care behaviors (general, medication, dietary) and patient characteristics such as age, gender, marital status or illness history. There was a significant relationship between costs and medication, and dietary self-care. The investigators defined costs as "measured in terms of side effects, discomfort, or inconvenience associated with medication or dietary self-care, and additional food costs growing out of the prescribed diet." (p.251). Stepwise multiple regression was used to identify predictor variables for self-care behaviors. The predictor variables were psychological status, costs, seriousness/vulnerability and health motivation.

The study gave support to the importance of psychological status, selfconcept and social support on a patient's ability to perform self-care. The investigators noted the need to frequently assess patients' self-care behaviors. Patients need to have continued educational input from health care providers to assist them in making appropriate decisions and maintaining self-care practices. 
Although the study did not examine outcomes of patients practicing these selfcare behaviors, it supported the need for patients with chronic illnesses to demonstrate self-care behaviors in order to cope successfully with their disease. Self-Care and Education

Another variable that has been found to affect self-care is the level of access to educational programs, which provide the client with the knowledge required to practice self-care effectively. Geller and Butler (1981) interviewed 78 patients admitted for diabetic complications to a hospital over a one year period. Their purpose was "to determine the importance of educational deficits as factors resulting in hospitalization for diabetes and its complications in a large community hospital setting." (p. 487). These researchers reported that about $50 \%$ of the patients had some form of an educational deficit, which were associated with hospitalization occurrences. Other causes of admission (43\%) described were psycho socioeconomic deficits and unavoidable admissions. Patients were selected consecutively with certain specified complications such as diabetic ketoacidosis and foot complications, and were interviewed and assessed by the endocrine resident. They were then presented at a monthly conference supervised by the chief of the endocrine service where they were evaluated for the reason for their hospitalization. There are several problems with this study. There was no indication of the content of the interview or of the parameters used in assessment. There was also no description of how subjects 
were evaluated and categorized as to the reason for admission. No statistical analysis of the data was presented. Although intuitively there may have been a basis for concluding that educational deficits affected self-care activities and resulted in hospitalizations, the data collection techniques and methodology used did not allow drawing such a conclusion.

Funnell and Haas (1995) reported on the national standards for diabetes self-management educational programs. Formal standards were established by the American Diabetic Association for recognition of programs that met the national standards. These standards were set by the National Advisory Board in collaboration with other diabetes related groups, and were revised in 1993 to reflect current health care directions. Diabetes education programs are referred to as self-management programs "to reflect the need for people with diabetes to manage their diabetes on a day-to-day basis." (p. 100). Again, the theme of fostering self-care agency in patients with the chronic disease of diabetes is emphasized.

Glasgow (1995) proposed a model for diabetes management and education in which there are three levels: 1) social environment and contextual factors, 2) patient-health care provider interactions, self-management behaviors, and short-term psychological outcomes and 3) longer term health and quality-oflife outcomes, which include the major societal costs of treating diabetes complications. (p. 117). This article addressed the first two levels in considerable 
detail, but did not delve into the third level dealing with outcomes. It is at this third level that one would expect to find concerns such as poor metabolic control, repeated hospitalizations, and other quality of life issues.

$\underline{\text { Self-Care and Health Beliefs }}$

Connelly's (1993) model of self-care utilizes Becker's Health Belief Model as its basis. The Health Belief Model has been well utilized in predicting patient compliance. Peyrot and Rubin (1994) studied patients in an outpatient diabetic education program in order to examine the structure and correlates of a diabetes-specific locus of control. The subjects in this study were primarily white males with an average age of 47.4 years. Most subjects had at least some college education. The study measured diabetes locus of control, glycemic control, self-care behavior, and emotional well-being. These variables were measured at the beginning of the program, at the end of the program, and at six months and twelve months later via a mailed questionnaire. (Response to the questionnaire was $73 \%$ and $61 \%$ respectively). Results showed that internal diabetes locus of control had two components -- autonomy and self blame. Autonomy was significantly associated with positive outcomes and self blame was generally associated with negative outcomes. The conclusions were: 1) some diabetics believed that they were responsible for their health including abnormal blood glucose levels; 2) there were others who believed that they actually could control their disease but did not and thus blamed themselves for 
poor outcomes; 3) self blame might be a consequence of poor self-care, and thus might discourage clients from participating actively in their own care 4) autonomy could lead to positive emotional and diabetes specific outcomes, and successful self-care could increase autonomy. There was also an external component which was associated with better health outcomes. External components consisted of health professionals and non-medical others. The recommendations from this study were that health professionals should structure interventions to allow the patient to take control of their health while utilizing support from external sources. The patients identified at risk for health problems were those who believe that health outcomes are controlled primarily by chance.

The link between self-care and perceptions has been addressed by Keller, Ward, and Baumann (1989). They recognized that self-care incorporates many processes. These authors stated that, " research in this area suggests that self-care behaviors are largely a product of subjective perceptions, that is, people behave according to what they believe and how they feel" (p.54). Keller. Ward and Baumann described the Common Sense Model as "an information processing model in which individuals are seen as motivated to construct meanings for body sensations in order to engage in self-regulating behaviors" (p. 55). The model has been used to study type II diabetic patients and their use of symptoms to monitor their diabetes. The inference is that some patients 
believe that they can have some control over the disease process, and may consciously be able to change or select behaviors to achieve this goal.

\section{Self-Care and Compliance}

Tamez and Vacalis (1990) studied compliance in a group of hospitalized Mexican American diabetic patients. The patients were enrolled in an educational program which was divided into three groups -- patients only, significant others only, and a group with both patients and significant others. The patients were followed as outpatients to see whether there was any effect on their compliance based on the type of group instruction given, and also whether those patients with high beliefs in chance complied less, regardless of their group assignment. Health beliefs were measured using the multidimensional health locus of control scale. The results were that increased compliance was associated with empowerment of the significant other. This is in agreement with the study by Peyrot and Rubin discussed earlier. Contrary to expectations, neither internal health locus of control nor chance health locus of control had any significant effect on compliance behavior, regardless of group assignment. This is different from the findings of the Peyrot and Rubin study, and could be due to cultural differences between the groups studied and to the differences in populations studied. Further evaluation would be needed to see if patients with a high chance locus of control are indeed at risk for health problems as suggested by the Peyrot and Rubin study, or not at risk, as suggested by the 
Tamez and Vacalis study.

Self-care and Diabetic Complications

A large portion of the devastation caused by diabetes mellitus lies in the associated and diverse complications, and the contribution to the development of other diseases. Poor glycemic control has been long associated with complications of diabetes. In a study performed by Fishbein (1985), poor diabetes control (noncompliance with diet/medication) and infections were found to be precipitating factors for admissions in almost $50 \%$ of the 641 diabetics used for the study. Similar results were found by Wrigley and Mayou (1991) who examined the relationship between psychological factors, social factors and acute admissions for poor diabetic control. In the study by Wrigley and Mayou, infections accounted for about a third of the admissions with the other two thirds were attributed to poor control resulting from inadequate self-care.

Sena and Fox (1991) calculated the hospitalization rates for late complications in diabetic patients and compared these with an age-matched and sex-matched control group. Late complications were identified as development of ophthalmic, renal, neurological, cerebrovascular, cardiovascular, and peripheral vascular disease. A total of 1,206,362 hospitalized diabetic patients and a total of $4,696,189$ hospitalized non-diabetic patients were reviewed. They found that the rate of hospitalization was much higher for diabetic patients in each group as compared to the non-diabetic patients. Hospitalization rates were 
especially high for the diabetic patients with neuropathies and circulatory diseases. Leese (1992) also noted similar results in terms of costs of complications in Great Britain and other European countries.

In summary, self-care and health beliefs have been implicated in various degrees in the successful or unsuccessful management of diabetes mellitus. The practice of self-care incorporates the patients' belief systems and these beliefs influence the decisions that they make. It is commonly accepted that self-care is an essential part of successful diabetes management. The quality of life of the diabetic patient may be directly or indirectly linked to the level of self-care that is practiced, and the health beliefs of the patient. Few studies have been done which sought to identify if any relationships exist among self-care perceptions, health beliefs and the degree of metabolic control in diabetic patients. If the practice of certain self-care behaviors can be associated with the positive health outcome of better metabolic control, then efforts need to be further intensified to teach all diabetics these behaviors. In addition, information should be provided that will assist the patient to adopt health beliefs that are positive, and to exert as much control as possible over the preventable aspects of the disease process. The assumption is that these are learned beliefs and not personal inborn characteristics.

Conceptual framework

The framework for this study was based on Dorothea Orem's theory of 
Self-Care. Orem (1980) described three theoretical constructs to her theory which are: 1) the theory of self-care deficit (predicts nursing requirements and identifies those in need of nursing, 2) the theory of self-care ( structured actions promoting human functioning and development) and 3 ) the theory of nursing systems (explains how persons can be helped through nursing). (p.26). Orem also subscribes to the idea that self-care is a learned behavior. Self-care encompasses actions that are deliberate and performed to enhance growth and functioning of the human body. As such, compliance and positive health perceptions are parts of these deliberate actions undertaken by clients in order to satisfy self-care needs and maintain equilibrium between self-care demands and self-care capabilities.

Nurses are constantly evaluating their patients to identify opportunities for health promotion and positive health outcomes. Actions are taken to facilitate patients in their self-care practices and decrease dependence on those around them. Nurses also recognize those situations where patients may have already decompensated, and act toward preventing any further deterioration while assisting them back to their normal state of health and well-being. This would be described by Orem as moving the patient from a wholly compensatory system to one that is mainly supportive-educative. Appropriate interventions can be made when the health care provider is able to recognize factors and the degree to which they are influential on the patient's actions. 
In this study, self-care deficits and actions were identified through the questionnaires administered. The results of the research will be used to identify ways in which the patients may be helped through nursing. 


\section{Chapter 3}

\section{Methodology}

This chapter will describe the study design, setting, sampling, procedure and data analysis techniques used.

\section{Study Design}

This study sought to explore the relationships among self-care perceptions, health beliefs and metabolic control of non-insulin-dependent diabetic patients. The influence of socio-demographic factors on self-care perceptions and health beliefs were also explored. The study was carried out using a descriptive, correlational design.

\section{Population Characteristics and Setting}

The target population consisted of outpatient non-insulin-dependent diabetic adults, 35 years of age or older, at a 1500-bed teaching hospital in a large metropolitan area in the southeastern United States. For inclusion in the study, subjects were diabetic outpatients who had been followed for their diabetes care in one of the hospital's outpatients' clinics or satellite facilities for twelve months or more.

Excluded was any patient with:

(1) end stage renal disease

(2) gestational diabetes 
(3) severe cardiomyopathy

Sampling

A convenience sample was obtained from outpatients who were being followed in the clinic setting for non-insulin-dependent diabetes mellitus. Using the procedure for power analysis (Cohen, 1988) it was determined that a sample size of 85 subjects would be necessary to achieve statistical significance ( $p$ value of .05 , power of $80 \%$, effect size $=.30$ ). Potential subjects were identified from the daily appointment schedules for the diabetes, internal medicine and family medicine clinics. Those who met the study criteria were asked to participate in the study. Initially, the planned time for data collection was three months. However, at the end of this time, only about 15 subjects had been enrolled, and so the data collection period was extended for another two months. In addition, a satellite clinic of the institution was added to the primary clinic sites. By adopting these modifications, a total of 52 subjects was enrolled. (This resulted in a decrease in power to $57 \%$ for the $p$-value of .05 and effect size of .30$)$.

\section{Data Collection Instruments}

The Exercise of Self-care Agency (ESCA) (Kearney and Fleischer, 1979) was used to measure general self-care agency perceptions of the subjects (Appendix B). Kearney and Fleischer (1979) developed the 43 item ESCA instrument to measure exercise of self-care agency of an individual. Thirty-three 
items are positively oriented toward self-care, and 10 items $(3,6,10,16,19,22$, $25,28,34$, and 39 ) are negatively worded with respect to exercise of self-care. Measurement is done using a 5-point Likert-type scale. Indicants of self-care agency are an attitude of self-responsibility, motivation for self-care, the application of knowledge to self-care, value for health priorities and high selfesteem. The researchers used nursing and psychology students as subjects. Content validity was established using a panel of five experts, and construct validity by comparing the ESCA to the Adjective checklist and the Rotter Internal-External Locus of Control Scale. The ESCA has been examined for reliability and construct validity by McBride (1987) who used the scale on nursing students and diabetic patients. Reisch and Hauck (1988) tested the instrument for construct and discriminant validity in three groups: pregnant women and their coaches, healthy adolescents, and university faculty, staff and students.

The Diabetic Patients' Health Belief Scales were developed by Given, Given, Gallin and Condon (1983) to measure patient compliance and health beliefs specifically in diabetic patients (Appendix $C$ ). There were originally twelve constructs from which six final scales were derived. The six scales are: control of effects of diabetes, barriers to diet, social support for diet, benefits of therapy, barriers to taking medication, and impact of the job on therapy. These scales were found to be internally and externally consistent across both samples 
in which they were used. Validities of the scales were not reported. Wooldridge, Wallston, Graber, Brown and Davidson (1992) modified and used the scales in measuring the health beliefs in an adult diabetic outpatient population.

A Demographic Data Collection Sheet designed by the researcher was used to collect background information (Appendix D).

Data on metabolic control was recorded using the Metabolic Control-Data Collection Sheet designed by the researcher (Appendix E). This included data from the medical records of serum glucose and/or glycosylated hemoglobin values of the subjects.

\section{Data Collection Procedures}

Prior to the start of data collection, the research assistant was thoroughly familiarized with the design of the study and with the data collection tools. The method of administering the questionnaires was reviewed.

Subject recruitment was started once approval was secured from the institutional review boards of the University and the hospital. Subjects who met the criteria were identified from review of the daily clinic roster.

Patients were approached in the clinic by the principal investigator or assistant, who introduced themselves and then provided some brief information about the study. The patients were then invited to participate in the study, and were encouraged to ask further questions about the study. The patients were also assured that confidentiality would be maintained. Written consent was then 
obtained from those individuals who agreed to participate. The questionnaires were then orally administered by the researcher or assistant (who spoke Spanish) during the clinic visit while subjects were waiting to be seen by medical personnel. The order of administration for the questionnaires was: the demographic data collection sheet, followed by the ESCA, and lastly, the Diabetic Patients' Health Beliefs Scales. The questionnaires were completed in an average time of about 25 minutes. The Metabolic Data-- Collection Sheet was then completed by recording the three most current and available values of the glycosylated hemoglobin tests and/or serum glucose values from the patient's medical records. Data were collected over a period from July 1996 to November 1996.

\section{Methods of Data Analysis}

Descriptive statistics were calculated for socio-demographic data. Frequency distributions were estimated. The generalized association statistic value of the Cochran-Mantel-Haenszel $(\mathrm{CMH})$ statistics and Pearson's productmoment correlation coefficient (Pearson's $r$ ) were computed to determine any relationships among perceptions of self-care, health beliefs and metabolic control. Influences of socio-demographic factors were also explored. The level of significance, alpha, was set at .05 in this study. Thus, the value to reject the null hypothesis $H_{0}$ of no linear relationship was set at $p \leq .05$. 


\section{Chapter 4}

\section{Results}

The results of the study are presented in this chapter, beginning with descriptive data on the characteristics of the sample. The analysis of the data that were obtained and the findings of the hypothesis testing are also described. Sample Characteristics

A total of 52 patients was obtained for the study. This was lower than the desired size of 85 for several reasons: 1) the same patients were repeatedly encountered on multiple visits by the researcher to the clinics, 2) many eligible patients did not wish to participate, and 3) time constraints for data collection.

Results presented in Table 1 showed that the sample consisted of 37 females $(71.2 \%)$ and 15 males (28.8\%). Ages ranged from 35 to 80 years, with the largest group (40.4\%) being between 55 and 64 years old, and next were 45 to 54 year olds (28.9\%). The subjects were predominantly Black Non-Hispanic (51.9\%). There were $36.5 \%$ Hispanic subjects, $7.7 \%$ White Non-Hispanic and 3.9\% Asian/Pacific Islander. The majority surveyed had no more than a high school education (61.5\%). Most (44.2\%) were married and $(71.2 \%)$ of the subjects had an income level of less than $\$ 10,000$ per year. There was some social support for most of the subjects as it was found that $78.8 \%$ lived with someone, and $76.9 \%$ responded that they had someone to help them at home. 
Most patients had been diagnosed with diabetes three to five years (32.7\%), but a significant amount $(26.9 \%)$ had been diagnosed for more than 10 years. Table 1 presents the socio-demographic characteristics of the sample. 
Table 1

Socio-demographic Characteristics of Sample $(n=52)$

\begin{tabular}{|c|c|c|}
\hline Variable & Frequency & Percent \\
\hline \multicolumn{3}{|l|}{ Age (years) } \\
\hline $35-44$ & 6 & 11.5 \\
\hline $45-54$ & 15 & 28.9 \\
\hline $55-64$ & 21 & 40.4 \\
\hline $65-80$ & 8 & 15.4 \\
\hline${ }^{*}$ missing data & 2 & 3.8 \\
\hline \multicolumn{3}{|l|}{ Sex } \\
\hline Female & 37 & 71.2 \\
\hline Male & 15 & 28.8 \\
\hline \multicolumn{3}{|l|}{ Education } \\
\hline Grade School & 15 & 28.9 \\
\hline High School & 32 & 61.5 \\
\hline Associate Degree & 2 & 3.9 \\
\hline Bachelors Degree & 1 & 1.9 \\
\hline Graduate Degree & 1 & 1.9 \\
\hline${ }^{*}$ missing data & 1 & 1.9 \\
\hline
\end{tabular}




\begin{tabular}{|c|c|c|}
\hline Variable & Frequency & Percent \\
\hline \multicolumn{3}{|l|}{ Marital Status } \\
\hline Single & 5 & 9.6 \\
\hline Married & 23 & 44.2 \\
\hline Divorced & 9 & 17.3 \\
\hline Widowed & 11 & 21.2 \\
\hline Separated & 4 & 7.7 \\
\hline \multicolumn{3}{|l|}{ Ethnic Group } \\
\hline Black non-Hispanic & 27 & 51.9 \\
\hline White non-Hispanic & 4 & 7.7 \\
\hline Hispanic & 19 & 36.5 \\
\hline Asian/Pacific & 2 & 3.9 \\
\hline Islander & & \\
\hline Native American & 0 & 0.0 \\
\hline Other & 0 & 0.0 \\
\hline
\end{tabular}




\begin{tabular}{|c|c|c|}
\hline Variable & Frequency & Percent \\
\hline \multicolumn{3}{|l|}{ Income Level } \\
\hline$<\$ 10,000$ & 37 & 71.2 \\
\hline$\$ 10,000-\$ 19,999$ & 12 & 23.1 \\
\hline$\$ 20,000-\$ 29,999$ & 1 & 1.9 \\
\hline$\$ 30,000-\$ 39,999$ & 1 & 1.9 \\
\hline$\$ 40,000-\$ 49,999$ & 1 & 1.9 \\
\hline$>\$ 50,000$ & 0 & 0.0 \\
\hline \multicolumn{3}{|l|}{ Diabetes diagnosed } \\
\hline $1-2$ years & 11 & 21.2 \\
\hline $3-5$ years & 17 & 32.7 \\
\hline $6-8$ years & 8 & 15.4 \\
\hline $8-10$ years & 2 & 3.8 \\
\hline$>10$ years & 14 & 26.9 \\
\hline
\end{tabular}




\begin{tabular}{lcc}
\hline Variable & Frequency & Percent \\
\hline Live alone? & 41 & 78.8 \\
No & 11 & 21.2 \\
Yes & & \\
Help at home? & & \\
No & 12 & 23.1 \\
Yes & 40 & 76.9 \\
\end{tabular}




\section{Metabolic Control Profile}

Glycosylated hemoglobin values were available for 38 of the 52 subjects.

The majority $(47.4 \%)$ of these values were in the very poor range; $36.8 \%$ were in the poor range; $13.2 \%$ were acceptable, and $2.6 \%$ were in the good range.

Table 2 shows these results.

Table 2

Glycosylated Hemoglobin Values $(n=38)$

\begin{tabular}{lcc}
\hline Category & Frequency & Percent \\
\hline Good $(\leq 6 \%)$ & 1 & 2.6 \\
Acceptable $(6.1 \%-7 \%)$ & 5 & 13.2 \\
Poor $(7.1 \%-10 \%)$ & 14 & 36.8 \\
Very Poor $(\geq 10 \%)$ & 18 & 47.4 \\
\hline
\end{tabular}


Serum fasting glucose values were obtained from the medical records for 51 of 52 subjects. Again, the majority (68.7\%) of these values were in the poor or very poor range. These results are presented in Table 3.

Table 3

Serum Fasting Glucose Values ( $n=51$ )

\begin{tabular}{lcc}
\hline Category $(\mathrm{mg} / \mathrm{dl})$ & Frequency & Percent \\
\hline Good $(\leq 115)$ & 9 & 17.6 \\
Acceptable $(>115<140)$ & 7 & 13.7 \\
Poor $(>140<200)$ & 16 & 31.4 \\
Very Poor $(>200)$ & 19 & 37.3 \\
\hline
\end{tabular}




\section{Findings}

Question 1: What are common perceptions of self-care behaviors in non-insulin-dependent diabetic adults?

The ESCA was used to determine the subjects' perceptions of their exercise of self-care agency. Four subconstructs contribute to a person's exercise of self-care agency. They are initiative and responsibility, self-concept, knowledge and information-seeking, and passivity. Those items that were positively oriented to self-care were scored from 4 for a response of "very characteristic of me" to 0 for a response of "very uncharacteristic of me". Scores were reversed for items worded negatively with respect to self-care. The maximum possible total score was 172 , with a minimum possible score of 0 . High scores indicate a high level of exercise of self-care agency. This questionnaire was completed by 50 of the 52 subjects with a mean score of 126 , a range of 73 to 162 and a standard deviation of 20.6 .

To identify the self-care behaviors of those surveyed, most of the respondents must have answered "very characteristic" or "somewhat characteristic" to a positively oriented question, and "very uncharacteristic" or "somewhat uncharacteristic" to a negatively worded question. (This meant that most respondents answered with a score of 3 or 4). Fifteen items rated initiative and responsibility; fourteen rated self-concept; eight items rated passivity; and six rated knowledge. 
In 14 of the 15 questions covering the sub-construct of initiative and responsibility, the majority of respondents $(>55 \%)$ reported that these were characteristic behaviors. The question "I usually try home remedies that have worked in the past rather than going to see a nurse or doctor for help" was rated by $62 \%$ as uncharacteristic.

Self-concept was also rated strongly. This was indicated in all 14 questions covering this area having more than two-thirds of the subjects agree (with a score of 3 or 4 ) that high self-concept was a self-care characteristic. The two questions which were ranked lowest (score of 2 or less) were "I do not contribute to my family's functioning" and "I have little to contribute to others." Many of the subjects may have interpreted these questions as meaning financial contributions only, since when asked these questions, many of the subjects remarked that they had little or nothing to give since they did not work outside the home. As it was noted in the demographic results, most subjects earned less than $\$ 10,000$ per year.

There was a greater spread of answers in the questions which were asked to identify passive behaviors. There were $73.1 \%$ of respondents that answered at least "characteristic" to the question "I often feel I lack the energy to care for my health needs the way I would like to", while $80 \%$ responded "characteristic" or "very characteristic" to the question "when I have problems, I usually want an expert to tell me what to do." These answers would indicate 
passive behaviors. The item "I complain a lot about things that bother me without doing much about them" was the only 1 of 8 in which there was a markedly higher percentage ( $70 \%)$ of those selecting "uncharacteristic" than of those who selected "characteristic" (30\%). The other five remaining questions had responses almost equally split between those who selected "characteristic" and those who selected "uncharacteristic".

Most subjects reported that they were knowledgeable about their bodies, and that they desired information to help them to care for themselves. This was reflected by more than $71 \%$ of the subjects answering at least "characteristic" on all six items.

Table 4 reflects the mean overall scores, and mean scores for the subconstructs. The mean score for a subconstruct is derived from all the items which comprise the subconstruct, and gives a general impression of the subjects' perceptions in that category. 
Table 4

Subjects' Scale Means for the ESCA

\begin{tabular}{lllll}
\hline Variable & $\mathrm{n}$ & Mean & SD & Maximum \\
\hline Total ESCA & 50 & 126 & 20.6 & 172 \\
Init/Resp & 52 & 3.090 & 0.506 & 4.000 \\
Self-concept & 52 & 3.289 & 0.242 & 4.000 \\
Passivity & 52 & 1.821 & 0.532 & 4.000 \\
Knowledge & 50 & 3.187 & 0.215 & 4.000 \\
\hline
\end{tabular}

Note. Init/Resp = Initiative and responsibility.

Minimum score is zero for total ESCA and for each subconstruct. 
Question 2: What are some health beliefs of non-insulin-dependent diabetic adults?

The Diabetic Patients' Health Belief Scales were used to measure the patients' beliefs about the effects of diabetes on their lifestyles, (four items); the barriers to following their diet, (five items); social support for diet, (four items); barriers to taking medication, (four items); the impact of the job on therapy, (seven items); and commitment to benefits of therapy, (eleven items). A score of five was assigned to an answer of "strongly agree" to a score of one for "strongly disagree." Scores were reversed for negatively worded items. The seven questions concerning the impact of the job on therapy were deleted from further analysis since the majority of subjects did not work. This gave a maximum possible score of 140 with this modification, and a minimum possible score of 0 . A total of 49 subjects completed this questionnaire. The mean score was 108 , with a range of $87-132$, and a standard deviation of 12.6 . The higher the score, the more representative of a strongly held belief.

The health beliefs of these subjects were elicited by identifying those items where the respondents selected "strongly agree" or "agree" (or "strongly disagree" or "disagree" for negatively worded questions). In the category of the effect of diabetes on their lifestyle, most $(80 \%)$ believed that they were capable of controlling their diabetes. Many believed that their diabetes was wellcontrolled (74\%), but had an adverse effect on their lifestyles $(59.2 \%)$, and 
would cause them to be sick a lot (51\%).

In the category of barriers to diet, there was agreement among the respondents $(86 \%)$ that they had time to follow the prescribed diet. A significant amount $(72 \%)$ did not believe that their personal life or normal daily activities interfered with their diet, and $54 \%$ admitted that they had difficulty following the prescribed diet. Respondents were split in their answers to the item "I would have to change too many habits to follow my diet", (46.9\% agreed, and $49 \%$ disagreed).

In all four items which addressed social support for diet, between $54-72 \%$ of the subjects believed that they could count on someone such as a husband, wife or child for support or motivation in their diet and weight control.

There was general consensus in the responses on all 11 questions concerning commitment to the benefits of therapy. At least $85 \%$ of the subjects believed that their medication would help prevent complications and would help them to feel better. They also believed that they needed to take the medication despite any difficulties and even if they did not feel that they were improving. Similar responses were given for diet therapy.

The final category was barriers to taking medication. There was agreement in all four questions. More than $75 \%$ of subjects answered that they were interested in taking their medications regularly, and disagreed with the statements that taking their medications interfered with their normal habits or 
daily activities. A significant portion (71\%) reported no confusion about their prescribed medications. Table 5 shows the mean overall score and mean scores for the subscales of the Health Beliefs Scales.

Table 5

Mean Scores for the Diabetic Patients' Health Beliefs Scales

\begin{tabular}{lllll}
\hline Variable & $\mathrm{n}$ & Mean & SD & Maximum \\
\hline Total Scales & 49 & 108.0 & 12.6 & 140.0 \\
Lifestyle effect & 50 & 3.226 & 0.834 & 5.000 \\
Barriers/diet & 50 & 3.505 & 0.656 & 5.000 \\
Social supp. & 50 & 3.595 & 0.216 & 5.000 \\
Barrier/meds & 49 & 4.010 & 0.270 & 5.000 \\
Comm/ben & 50 & 4.482 & 0.128 & 5.000
\end{tabular}

Note. Barriers/diet= barriers to following diet, Social supp.=social support for diet, barrier/meds=barriers to taking medication, comm/ben=commitment to benefits of therapy.

Minimum score for the total scales is 1 , and for each subscale is 1. 
Question 3: To what extent do the health beliefs and self-care behaviors of these patients relate to their level of metabolic control?

The $\mathrm{CMH}$ generalized association statistic was computed for each item on the ESCA and on the Health Beliefs' Scales against the glycosylated hemoglobin level and serum glucose levels. There were only two items on the ESCA and one item on the Health Beliefs' Scales that were found to have a significant relationship $(p \leq .05)$ to glycosylated hemoglobin levels. The items from the ESCA were, "I complain a lot about things that bother me without doing much about them" ( $p=0.003)$, "I am interested in learning about various diseases processes and how they affect me" $(p=0.001)$ and from the Health Beliefs' Scales, "I would have to change too many habits to take my medication" $(p=0.033)$.

In addition, the relationship between perception of self-care behaviors and metabolic control was computed using Pearson's $r$ and no relationship was found $(r=.008, p=0.96)$. There was also no relationship between health beliefs and metabolic control $(r=0.013, p=.94)$. Correlational analysis was performed to identify any relationships between the subconstructs (in both tools utilized), and metabolic control. There were no significant relationships noted. These results indicate that self-care behaviors and health beliefs have little (if any) relationship to metabolic control. Intercorrelations among the subconstructs were also performed. The results of the correlational analyses are found in Tables 6 and 7 . 
Table 6

Intercorrelations Between Subconstructs of ESCA and Metabolic Control

\begin{tabular}{|c|c|c|c|c|c|c|c|}
\hline & 1 & 2 & 3 & 4 & 5 & 6 & 7 \\
\hline 1. $\mid / R$ & 1.0 & $.79^{\star}$ & -.09 & .71 & -.07 & .21 & $.84^{*}$ \\
\hline 2. $S / C$ & & 1.0 & .03 & 0.0 & .10 & .27 & $.88^{*}$ \\
\hline 3. Pass & & & 1.0 & .03 & -.07 & -.04 & $.34^{*}$ \\
\hline 4. $\mathrm{Kno}^{\mathrm{a}}$ & & & & 1.0 & .02 & .12 & $.79^{\star}$ \\
\hline 5. $\mathrm{G} / \mathrm{H}^{\mathrm{b}}$ & & & & & 1.0 & $60^{*}$ & .01 \\
\hline 6. $S^{c}$ & & & & & & 1.0 & .21 \\
\hline 7. SCB & & & & & & & 1.0 \\
\hline
\end{tabular}

knowledge, $\mathrm{G} / \mathrm{H}=$ glycosylated hemoglobin, $\mathrm{SG}=$ serum fasting glucose, $\mathrm{SCB}=$ self-care behaviors.

$n=52$ except otherwise indicated. ${ }^{a} n=50 .{ }^{b} n=38 . \quad{ }^{c} n=51$.

${ }^{*} p<.05$ 
Table 7

Intercorrelations Between the Health Belief Scales and Metabolic Control

\begin{tabular}{|c|c|c|c|c|c|c|c|c|}
\hline & 1 & 2 & 3 & $4^{a}$ & 5 & $6^{b}$ & $7^{c}$ & 8 \\
\hline 1. $E / L$ & 1.0 & .15 & .12 & $.28^{*}$ & .08 & .21 & .13 & $29^{\star}$ \\
\hline 2. $B / D$ & & 1.0 & .26 & .15 & $.49^{*}$ & .03 & .03 & $.72^{\star}$ \\
\hline 3. $S / S$ & & & 1.0 & .23 & .16 & .04 & -.09 & $.48^{\star}$ \\
\hline 4. $B / M$ & & & & 1.0 & -.24 & .01 & -.16 & $.41^{\star}$ \\
\hline 5. $\mathrm{C} / \mathrm{B}$ & & & & & 1.0 & .20 & .02 & $.59^{\star}$ \\
\hline 6. $\mathrm{G} / \mathrm{H}$ & & & & & & 1.0 & $.60^{\star}$ & .01 \\
\hline 7. SG & & & & & & & 1.0 & -.11 \\
\hline 8. $H / B$ & & & & & & & & 1.0 \\
\hline
\end{tabular}

Note. $E / L=$ effect on lifestyle, $B / D=$ barriers to diet, $S / S=$ social support for diet,

$\mathrm{B} / \mathrm{M}=$ barriers to taking medications, $\mathrm{C} / \mathrm{B}=$ commitment to benefits of therapy,

$\mathrm{G} / \mathrm{H}=$ glycosylated hemoglobin, $\mathrm{S} / \mathrm{G}=$ serum fasting glucose, $H / B=$ health beliefs.

$n=50$ except as otherwise indicated. ${ }^{a} n=48 .{ }^{b} n=38 .{ }^{c} n=49$.

${ }^{*} p<.05$ 
Question 4: To what extent does age or ethnicity or education or gender influence self-care perceptions and health beliefs?

The $\mathrm{CMH}$ generalized association statistic was calculated to explore any influence by these socio-demographic characteristics on self-care perceptions, or on health beliefs. Each response was tested against each characteristic. Twenty-one of 43 items relating to self-care, and 6 of 28 items relating to health beliefs were influenced by one or more of the characteristics of age, ethnicity, gender, or education. Of the 21 self-care items, eight were from the subconstruct of initiative/responsibility, eight from self-concept, three from knowledge and two from the passivity subconstruct. The six health beliefs items consisted of three from the commitment to benefits subscale, one from barriers to diet, one from barriers to medications, and one from the social support for diet subscale.

The results indicated that seven self-care items and one health belief item was significantly influenced by gender. Some of these items were also influenced by ethnicity and these are indicated.

"Over the years, I have noticed the things to do that make me feel better" $(p=.019)$

"I make my own decisions" ( $p=.003) ;($ also related to ethnicity, $p=.001$ )

"I know what foods to eat and keep me healthy" ( $p=.033)$;

"I feel I am a valuable member of my family" ( $p=.009$ ); (ethnicity, $p=.001$ ).

"I take good care of myself" ( $p=.019) ;($ ethnicity, $p=.002$ ); 
"I take pride in doing the things I need to do in order to remain healthy" $(p=.026) ;($ ethnicity, $p=.001)$;

"I remember when I had my last health check and return on time for my next one" $(p=.034)$.

The health belief item was: "I am confused by all the medication that the doctor has given me" $(p=.018)$.

Education had a significant influence on three self-care items and one health belief item. Ethnicity also played a role in one self-care item and this is indicated.

"I would gladly give up some of my set ways if it meant improving my health" $(p=.001)$

"If I am not good to myself, I believe I cannot be good to anyone else" $(p=.003)$

"I am a good friend to myself" $(p=.013)$;

"I am interested in learning about various disease processes and how they affect me" ( $p=.03)$; (ethnicity, .014).

Health beliefs: "Controlling weight is something one must do no matter how hard it is" $(p=.001)$.

Ethnicity was related to 15 self-care items and four health belief items.

The other items not previously mentioned were:

"I perform certain activities to keep from getting sick" ( $p=.005)$; 
"I strive to better myself" ( $p=.017)$;

"I eat a balanced diet" ( $p=.004)$;

"I complain a lot about things that bother me without doing much about them" $(p=.001)$

"I deserve all the time and care it takes to maintain my health" ( $p=.003)$;

"I follow through on my decisions" $(p=.001)$;

"Life is a joy" $(p=.025)$;

"I am interested in learning all that I can about my body and the way it functions" $(p=.001)$;

"I understand myself and my needs pretty well" $(p=.004)$.

Health beliefs: "Following my diet does not interfere with my normal daily activities" $(p=.008)$;

"I can count on my family when I need help following my diet" $(p=.027)$;

"I believe that my diet will help prevent diseases (complications) related to diabetes" $(p=.011)$

"I must follow my diet even if I don't think that I am getting better" $(p=.001)$. Age did not appear to have any influence at all on self-care perceptions or health beliefs ( $p>.05$ for all items). Black non-Hispanic, high school educated and female subjects were most associated with the more positive health beliefs and self-care behaviors.

In summary, the majority of subjects chose behaviors describing initiative 
and responsibility, high self-concept, and knowledge/information-seeking as characteristic of them. There was a mixed response to those items describing behaviors related to passivity in their self-care. Most believed that they were capable of controlling their diabetes, and did not identify any significant barriers to adhering to their diet. However, many did believe that the disease would have adverse effects on their lives. Nevertheless, the subjects believed in the need for commitment to therapy including taking their medication regularly. Health beliefs and self-care perceptions did not appear to be related to the level of metabolic control. The socio-demographic factors of ethnicity, education, and gender had a significant influence on some health beliefs and self-care perceptions. Ethnicity and gender appeared to play more major roles than education. 


\section{Chapter 5}

\section{Discussion and conclusions}

\section{$\underline{\text { Sample }}$}

The sample mainly consisted of middle-aged, Black non-Hispanic females with high school education. Most subjects were married, felt that they had some social support, and did not work outside the home. The diagnosis of diabetes had been made greater than five years.

The subjects' perceptions of their self-care behaviors included those that required initiative and self-responsibility, a strong self-concept, and active seeking of knowledge to care for themselves adequately. Their beliefs were that they were able to control their disease, and that they were committed to taking their medication and their diet as prescribed.

Discussion of findings.

The findings indicated that in general, the subjects had fairly positive health beliefs. They believed, for example, that they were able to control their disease, and reported a commitment to taking their prescribed medication. From the mean scores for the health beliefs subscales in this study (see Table 5), it appears that the health beliefs represented by all the scales are fairly strongly held. Given, Given, Gallin and Condon (1983) tested the health beliefs questionnaire in 152 patients with diabetes, and followed up with a second group of 92 patients for validation. The mean scores reported by these researchers 
were comparable to the present study in three areas: "the effects on lifestyle", "social support for diet", and "commitment to benefits". Scores in the other two constructs of "barriers to following diet" and "barriers to taking medication" were found to be much higher in the present study. A possible explanation may be found in the differences in ethnicity, since most of the other sample characteristics were similar. There were a majority of Black non-Hispanic patients in this study compared to predominantly white patients in the other study. Cultural differences may have influenced how questions were answered. This would need to be followed up with further studies. It was also not specified what type of diabetic patients were being followed in the 1983 study. This could have also contributed to the differences in results.

Despite the findings of strongly held health beliefs and the perception of good self-care practices, almost all of the subjects had glycosylated hemoglobin and serum glucose levels that were in the "poor" or "very poor" range of control. A close look at the responses revealed that there were some contradictions in the reported behaviors. For example, they perceived that they practiced adequate self-care behaviors and took good care of themselves. However, many also reported that they did not have the energy to care for themselves. Thus, they may have reported health beliefs that did not actually translate into actions. Additionally, many did not agree with or believe to be characteristic of them, some of those items that asked about specific and concrete self-care behaviors 
such as sticking to a prescribed diet, or having a planned exercise program. Several either did not have or could not count on a family member or other person to support them with their self-care activities, which meant in these cases that the patient bore full responsibility for self-care actions. Also to be noted, is the borderline score on the passivity subconstruct of the ESCA. In contrast to the other subconstructs, passivity was not strongly denied as a characteristic behavior. In fact, it was characteristic of almost half of the subjects. These are some of the key factors that would have a direct effect on metabolic control, and could explain the apparent contradictions between reported characteristics and the expected outcome of adequate metabolic control.

No relationship was found among perceptions of general self-care behaviors, health beliefs and metabolic control. Wooldridge, Wallston, Graber, Brown \& Davidson (1992) reported similar results in their study. These researchers investigated whether health beliefs could be modified by a clinical education program and whether health beliefs were related to adherence to selfcare instructions and metabolic control of diabetes. Their findings were that some health beliefs could be modified by education, but they also were unable to directly associate metabolic control with any health belief, or any self-reported adherence.

In this study, there was no significant relationship between health beliefs and metabolic control. Also, there were no significant relationships between the 
subconstruct of knowledge and metabolic control; commitment to benefits of therapy and metabolic control; social support and metabolic control, or barriers to adherence and metabolic control. Brown and Hedges (1994) utilized a metaanalysis approach to predict and explain metabolic control in diabetes. The data from a total of 17 studies done over a period of nine years were used. The predictors used were knowledge, health beliefs, (with subscales of barriers, commitment, cues, expectancies, impact on lifestyle, support, and susceptibility) and compliance/adherence.

The findings indicated that composite health beliefs had a weak or negligible effect on metabolic control, knowledge had a negative direct effect, and both variables had indirect effects through compliance. The individual health beliefs' scales components had direct and indirect effects, depending on the component. For example, commitment to benefits of therapy had a direct effect on metabolic control, barriers had an indirect effect through compliance, knowledge had an inverse direct effect and a positive indirect effect through compliance.

It can be seen then that the lack of a relationship between composite health beliefs and metabolic control is supported by the Brown and Hedges meta-analysis. However, there is a difference in the results from the subconstructs and metabolic control. While it is unknown how much diabetes education the subjects of the present study may have had, recall that the mean 
score on the knowledge subconstruct was fairly high. From the results of previous studies in the literature, this would lead one to expect that there would be a negative correlation with metabolic control. However, the majority of subjects also had no more than a high school education which may have changed the expected effect. Also, it appeared that education was not a predominant factor in this study since there was only minimum influence on health beliefs or self-care by this variable.

Ethnicity was noted to have a significant influence on some self-care perceptions and health beliefs. Several of these beliefs related to obtaining knowledge about the disease, and also their beliefs in themselves as valuable human beings. These influences will need to be studied further to identify precisely the type of knowledge that is needed. It is possible that patients may not have received the needed information about their disease; or may have had the knowledge about self-care, but not actually have been able to carry out the behaviors due to financial or other constraints. This in turn allows for greater more difficult glycemic control, and a greater chance of the development of complications.

Age did not appear to have any influence on self-care perceptions or health beliefs. This implies that self-care perceptions and health beliefs may be developed and maintained over a long period. It may be beneficial to explore how timing of interventions over a lifetime may influence the formulation of 
healthy beliefs and self-care habits.

It has been reinforced that there are other factors apart from self-care behaviors and health beliefs which influence metabolic control. Further studies into causes as well as relationships must be pursued.

\section{Limitations}

Self-care behaviors were measured by self-report from the participants. Many of the questions were of a subjective nature which has inherent problems. It is always a possibility that participants will give answers which they believe to be the "acceptable one" rather than their true opinions. There were no follow-up visits to the participants' homes or direct observation of behaviors to verify any of the information given. In the literature, self-reporting has been reported as a weak link in carrying out studies of this nature. Thus, there may exist a gap between perceptions and actual behaviors which would not be captured without follow-up or direct observation. In addition, metabolic control as well as self-care may be affected by several other factors such as severity of disease, presence of other chronic health conditions, and financial resources. This study did not address the individual effects of factors such as these.

There was difficulty interpreting the results because of the small sample size. This reduced the power to $57 \%$ which was much lower than desired. It is possible that results may have been different if the intended sample size had been obtained. Several potentially eligible Hispanic subjects were missed 
because the Spanish-speaking research assistant was involved with other interviews or may have been unavailable at that time. Also, the length of the questionnaires may have discouraged a few patients. Despite assurances to the contrary, some were unwilling to participate because of the fear that they would have a delay in seeing their health care provider.

A few of the items (especially those negatively worded) on the tools may have posed a problem for some subjects with a lesser educational level. Some of these were identified beforehand, and strategies were discussed on rewording to enhance clarity. This may have contributed to some skewing of scores. However, reliability scores were computed using Cronbach's alpha coefficient, and were found to be .88 on the ESCA, and .66 on the Health Beliefs' Scales, which were comparable to scores reported by the authors of the instruments. Recommendations for future research

Further research is needed to identify the specific impact of self-care and health beliefs on metabolic control. There are still no clear-cut conclusions on what factors influence metabolic control, and the extent of influence.

Any replication of this study should utilize a larger sample size, so that results could be generalized. The instruments used would also need to be reevaluated for clarity and length, depending on the population that will be studied. The use of a qualitative approach could also be useful in order to more accurately capture the perceptions and beliefs of the subjects expressed in their 
own words. The effects of sociodemographic factors will also need to be clarified.

\section{Nursing Implications}

The perceptions and some health beliefs of patients with non-insulin dependent diabetes have been presented in this paper. A better understanding of these patients' beliefs can assist in selecting appropriate methods that health care providers can use to plan and give care. For example, it is important to continue to utilize available social services to provide support to those who may not have family members or friends to fill this need. The emphasis then is on assisting these patients to find ways to close the gap between their perceptions and behaviors, or to increase their motivation, understanding and performance of self-care.

From the review of the literature, no instances were found in which the Exercise of Self-care Agency or the Diabetic Patients' Health Beliefs Scales were administered in Spanish or Creole. Both instruments were translated and back translated by three people. Reliability scores have been reported for both instruments. This allows for comparisons with future studies, which then is an important contribution to nursing from this study.

This study along with others reported in the literature has presented results that suggest that the extent of the influence of self-care and health 
beliefs on metabolic control is still unknown. However, nurses must still continue to provide patients with information which will help them to formulate positive health beliefs and self-care practices. The stability of the disease, prevention of complications, and improved quality of life is our long-term goal. 


\section{REFERENCES}

American Diabetes Association. (1995). Standards of medical care for patients with diabetes mellitus. Diabetes Care, 18, Suppl.1, 8 - 15.

Anderson, J. M. (1990). Home care management in chronic illness and the self-care movement: an analysis of ideologies and economic processes influencing policy decisions. Advances in Nursing Science, 12, 71 - 83.

Aro, S., Kangas, T., Reunanen, A., Salinto, M., \& Koivisto, V. (1994). Hospital use among diabetic patients and the general population. Diabetes Care, $17,1320-1329$.

Brown, S. A., \& Hedges, L. V. (1994). Predicting metabolic control in diabetes: a pilot study using meta-analysis to estimate a linear model. Nursing Research, 43, 362-368.

Connelly, C. E. (1993). An empirical study of a model of self-care in chronic illness. Clinical Nurse Specialist, 7, 247 - 253.

Connelly, C.E. (1987). Self-care and the chronically ill patient. Nursing Clinics of North America, 22, $621-629$.

Corbin, J.M., \& Strauss, A. (1991). A nursing model for chronic illness management based upon the trajectory framework. Scholarly Inquiry for Nursing Practice: An International Journal, 5, 155 - 173.

Dodd, M. J. (1988). Patterns of self-care in patients with breast cancer. Western Journal of Research, 10, 7 - 24. 
Fishbein, H. A. (1985). Precipitants of hospitalization in insulin-dependent diabetes mellitus (IDDM): a statewide perspective. Diabetes Care, 8(Suppl. 2), $61-64$.

Fitzpatrick, J. J., \& Whall, A. L. (1989). Conceptual models of nursing (2nd ed.). East Norwalk:Appleton.

Funnell, M. M., \& Haas, L. B. (1995). National standards for diabetes selfmanagement education programs. Diabetes Care, 18, 100 - 116.

Geller, J., \& Butler, K. (1981). Study of educational deficits as the cause of hospital admission for diabetes mellitus in a community hospital. Diabetes Care $4,487-489$.

Germain, C. P., \& Nemchik, R. M. (1988). Diabetes self-management and hospitalization. Image: Journal of Nursing Scholarship, 20, 74 - 79.

Given, C. W., Given, B. A., Gallin, R. S., \& Condon, J. W. (1983). Development of scales to measure beliefs of diabetic patients. Research in Nursing and Health, 6, $127-141$.

Glasgow, R. E. (1995). A practical model of diabetes management and education. Diabetes Care, 18, $117-126$.

Hays, R.D., Kravitz, R.L., Mazel, R.M., Sherbourne, C.D., DiMatteo, M.R., Rogers, W.H., \& Greenfield, S. (1994). The impact of patient adherence on health outcomes with chronic disease in the Medical Outcomes Study. Journal of Behavioral Medicine, 17, 347 - 360. 
Holden, E.W., \& Hodgens, J.B. (1987). Test of diabetes knowledge. In D.J. Keyser \& R.C. Sweetland (Eds.), Test critiques: Vol. 6 (pp.594 - 600). Kansas City: Test Corporation of America.

Jacobs, J., Sena, M., \& Fox, N. (1991). The cost of hospitalization for the late complications of diabetes in the United States. Diabetic Medicine, 8 , S23S29.

Kearney, B. Y., \& Fleischer, B. J. (1979). Development of an instrument to measure exercise of self-care agency. Research in Nursing and Health, 2,25 34.

Keller, M. L., Ward, S., \& Baumann, L. J. (1989). Processes of self-care: monitoring sensations and symptoms. Advances in Nursing Science, $12,54-66$.

Leese, B. (1992). The costs of diabetes and its complications. Social Science Medicine, 35, $1303-1310$.

Nordberg, B. J., Barlow, M. S., Chalew, S. A., \& McCarter. R. J. (1993). Effect of third-party reimbursement on use of services and indexes of management among indigent diabetic patients. Diabetes Care, 16, 1076 - 1080.

Orem, D. E. (1980). Nursing: concepts and practice (2nd ed.). New York: McGraw-Hill.

Peyrot, M., \& Rubin, R. R. (1994). Structure and correlates of diabetesspecific locus of control. Diabetes Care, 17, 994 - 1001.

Pollock, S.E. (1989). Adaptive responses to diabetes mellitus. Western 
Journal of Research, 11, $265-280$.

Tamez, E. G., \& Vacalis, T. D. (1989). Health beliefs, the significant other and compliance with therapeutic regimens among adult Mexican American diabetics. Health Education, 20(6), 24 - 31.

Wilson, B. E., \& Sharma, A. (1995). Public cost and access to primary care for hyperglycemic emergencies, Clark County, Nevada. Journal of Community Health, 20, $249-256$.

Wooldridge, K. L., Wallston, K. A., Graber, A. L., Brown, A. W., \& Davidson, P. (1992). The relationship between health beliefs, adherence, and metabolic control of diabetes. The Diabetes Educator, $18,495-500$.

Wrigley, M., \& Mayou, R. (1991). Psychosocial factors and admission for poor glycemic control: a study of psychological and social factors in poorly controlled insulin dependent diabetic patients. Journal of Psychosomatic Research, 35, 335 - 343. 


\section{APPENDIX A \\ INFORMED CONSENT}

Title of Study: An investigation of the relationships among self-care practices, health beliefs and metabolic control in the non- insulindependent diabetic adult.

Purpose of the study: This is a research study which is being done to identify self-care behaviors and health beliefs which may be related to the blood sugar levels in non-insulin-dependent diabetic patients. This research is being conducted at Florida International University by Sonia Anglin as the principal investigator (researcher). I am being asked to participate in this study because I am a non-insulin-dependent diabetic patient and I have been attending the diabetic clinic for the last year or more. I will be one of 100 subjects that are being asked to take part in this study.

Procedure: The researcher or assistant will ask me to answer questions about how I take care of myself as a diabetic, and also ask me to give some personal information such as my age, occupation, education, income level and length of time since I was told that I have diabetes. I expect that the whole process will take about 45 minutes of my time. I will be taken into an office or other available private room while I am being asked questions in order to protect my privacy. I am also being asked to give consent for the researcher to look at my medical records for reports of my blood sugar tests. 
Risks: There are no anticipated risks or discomforts to me by taking part in this study. The risks are no more than I would normally have in my ordinary, day-today activities.

Costs: Participation in the study will not cost me anything except for the time that I spend to answer the questions.

Benefits: There are no direct benefits to me by participating in this study. It is hoped that the information that I give will help to increase knowledge about what patients believe about diabetes, and how this may affect the way in which we care for ourselves. This will assist researchers to improve care for other diabetic patients in the future.

Alternatives: I may choose not to participate in this study.

Confidentiality: All information that I provide will be treated confidentially. My records will be kept confidential to the extent permitted by law. A code number will be placed on the papers containing my answers to questions and on the sheet of paper with information about my blood sugar levels from my medical records. I will not be identified in any way in publications. The information that I provide will be analyzed and reported as group data. All information will be kept in a locked file in the researcher's office during the study and for a period of three years after the study is completed, and then destroyed.

My rights: My participation in this study is completely voluntary. I can refuse to participate, or decide at any time to withdraw from the study without any ill-effect 
on my care. I may also refuse to answer any question with which I am uncomfortable. If I have questions about the study, I can contact the researcher Sonia Anglin at (305) 585-7100 or Dr. Divina Grossman, Major Professor, at (305) 919-5915. I may also request to know the results of the study by contacting the researcher. If I have any questions about my rights as a research subject, I can contact Maria Arnold, (Administrator, University of Miami Committee on Rights of Human Subjects) at (305) 243-3327. 
I agree of my own free will to participate in this study. I understand that I may withdraw from the study at any time without any ill-effects on my normal care to which I am entitled. I have read or had this consent form explained to me and have been given the right to ask questions concerning the procedure. I fully understand what is required of me and have been given a copy of this consent form.

I have read and understand all of the above.

Participant Signature

Date

I have explained and defined in detail the research procedure in which the participant has agreed to participate, and have offered him or her a copy of the informed consent form. 


\section{APENDICE A \\ INFORME DE CONSENTIMIENTO}

TITULO DEL ESTUDIO: Una investigacion sobre la relacion del cuidado personal, creencias de salud, y el control metabolico en el diabetico adulto que no necesita insulina.

PROPOSITO DE ESTUDIO: Este estudio es una investigacion con el proposito de identificar la relacion del cuidado personal y creencias de salud con los niveles de glucosa en la sangre del diabetico adulto que no necesita insulina. Esta investigacion sera conducida en la Universidad Internacional de la Florida, por Sonia Anglin que es la investigadora principal. Me han pedido mi participacion en este estudio porque soy un diabetico adulto que no necesita insulina y tambien me atiendo en la clinica diabetica por mas de un ano. Sere una de cien personas que participaran en este estudio.

PROCEDIMIENTO: La investigadora o asistente me va a preguntar como me cuido mi diabetes. Tambien me va pedir informacion personal como mi edad, ocupacion, educacion, ingresos y desde cuando tengo diabetes. Esta entrevista no demorara mas de 45 minutos. La entrevista sera en una oficina o cuarto privado para poder mantener mi privacidad. La investigadora me va pedir mi consentimiento para poder repasar los resultados de mis analisis de glucosa en la sangre.

RIESGOS: No se anticipa ningun riesgo o malestar por participar en este 
estudio. Los riesgos son los mismos que existen en la vida diaria.

COSTOS: Mi participacion en este estudio no me costara nada, solamente el tiempo que tome responder las preguntas.

BENEFICIOS: No existen beneficios directos por mi participacion en este estudio. Anticipan que mi informacion ayudara a educar a los pacientes con diabetes. Esta informacion les ayudara a los investigadores en el futuro a mejorar los tratamientos para los pacientes diabeticos.

ALTERNATIVAS: Yo puedo elegir no participar en este estudio.

CONFIDENCIALIDAD: Toda la informacion proveida sera tratada con confidencialidad. Mis archivos medicos seran tratados con privacidad como estipulado por la ley. Un codigo sera escrito en los papeles con mis respuestas a las preguntas y en otro papel la informacion sobre los niveles de azucar en la sangre de mi archivo medico. No sere identificado de ninguna forma en futuras publicaciones. La informacion que yo les dare sera analizada y reportada como data colectiva. Toda la informacion sera guardada en archivos bajo llave en la oficina de la investigadora durante la investigacion y por un periodo de tres anos. Esta informacion sera destruida cuando finalize el estudio.

MIS DERECHOS: Mi participacion en este estudio es completamente voluntaria. Puedo elegir no participar en este estudio. Puedo terminar mi participacion en este estudio en cualquier momento sin ninguna penalidad. Tambien puedo elegir a no contestar ciertas preguntas que puede que yo considere 
inapropiadas. Si tengo preguntas sobre este estudio puedo comunicarme con la investigadora Sonia Anglin al numero (305) 585-7100 o con la Dra. Divina Grossman, Profesora Mayor, al numero (305) 919-5915. Tambien puedo solicitar los resultados de este estudio llamando a la investigadora. Si tengo preguntas sobre mis derechos respecto a este estudio puedo comunicarme con Maria Arnold Administradora de el Comite de Derechos de Sujetos Humanos de la Universidad de Miami, (305) 243-3327. 
Yo estoy de acuerdo y por mi propia voluntad decido participar en este estudio. Yo comprendo que puedo decidir a no continuar con mi participacion en este estudio en cualquier momento. Yo he leido o me han explicado este consentimiento. Me han dado opurtunidad para hacer preguntas sobre este estudio. Yo entiendo completamente lo que requiere de mi esta investigacion. Me han dado copias de este consentimiento. Yo he leido y entiendo la informacion.

Firma del Participante Fecha

Yo le explique detalladamente los procedimientos de este estudio, con los cuales el participante esta de acuerdo. Yo le ofreci una copia de la forma de consentimiento.

Firma del Investigadora Principal Fecha

Testigo

Fecha 


\section{APPENDIX A \\ YON INFORMACION CONCENTI}

Tite pour Etudie: Yon anket ki gin relacion ant pratike swen sante pou ko ou ak metabolic control lan gran moun ki soufri suk nan pa pran insuline.

Proje etid la: Etid sa-a ce yon anket ki fet pou identifie fason ou compote tet ou lan sante ak maladi suk san ou sa bezoin sevi ak insuline. Anket sa-a-li fet lan Florida Intenacional Inivesite se Sonia Anglin ki chef investigate anket sila-a. Yo mande'm pou, mouin paticipe lan etid ca paske, moin soufri suk lan'm e moin pa sevi ak insuline e moin ap suiv clinic depi un an pace moin pra-c yon lan san baga-y yo mande pou fe lon etude ca.

Procedu: Ankee a ou bien assistan anpra-l pose ou kuesion ki gen ma-p ke come yon diabetik (maladi suk) e mande kose prive moin tan la-q moin, okipasion, education, profi ou fe lan trava-y. E kombien tan depi ou soufri suk (diabet). Mouin espere anket ca te ka pran 45 minuts, mete-m lan yon chamb prive, ofice le ya-p mande-m koze pou protégé vi prive-m. Yo te mande-m pou ba-y con centi pou anket, gade lan resulta suk san moin lan rapo medical moin. Ris: Pa gin okin ris ni discinfar pendan yap fe tes ca. Ris yo pa gin okin rapo avec travail ou.

Agents: Pou ou paticipe lipap koute lagent min lap repon ketion yo.

Beneficio: Pa gin benefis direct pou moin participe nan etude ca-a, moin espere infomasion ke'm di ou, a ede ogmente memoire maune ki cane nan diabeti (suk) 
e pi tau li ka affecte facon ou ocupe tet ou. Etide ca ka ede ankete ca yo join fason pou yo trete diabetes pacien yo nan lavenir.

Alternativ: Ou ka choisi pou ou pa paticipe nan etud ca a.

Gnou Secret: Tout infomasion ke im di ou supose confidentiel dapre la loi. Gin-in gnou numero secret ke y-ap mete nan papie ca a ke ap gining ketion'm ak repons e nan feuel papie ca ap gin infomasion de montant suck nan recordi medical mouin. Mouin pap identife nan okin piblications infomasion ke'm bayla ap analyze e reporte fankou group data. Tout infomasion ca yo ap kinbe nan gnou boite secret nan ofice ankete yo pendan etud la jiska troi (3) an juska etude la finni et ape ca yap jete yo.

Droi moin: Paticipation nan etud ca completment voliente. Mouin pa capab refuse pou paticipe ou bien decide nimpot ki le pou'm soti nan etid la san'l, pa fe $\mathrm{m}$ malad. Mouin capab refuse repon nimpet kestion ke'm mal concerne etud ca a mouin ka contacte ankete Sonia Anglin (305) 585-7100 oy bien Dr Divina Grossman, Major Professor. (305) 919-5915. Ouise bien mouin apab mande pou'm connin resulta etud la m'ap rele ankete a. Sim gen n'impot kestion conserne doi m com recherch man capab pran contact avec Maria Arnold (305) 243-3327 (Lise Administrator, University of Miami Comite nan droit sujet a nan). 
Mouin acepte entierement ak touo consent ment'm pou'm paticipe nan etid ca a. Mouin compran ke'm kapab soti nan etid la a nimpost kile san'l pa fem malad. Moun te li cinsentment form nan ki te explique e te su doi'm pou pose kestion concerne test-la. Moin conpren sa yo mande m e moiun te by gnou copy nan consentment form ca a.

Mouin li yo mouin conpran tout ca que seri an le a.

Participan sign

$$
\text { Date }
$$

Mmouin explique definition en detail anket test la, participan yo acepte pou paticipe e yo offri tout moun pou gnou copy form infomasion consentment ca a.

$\overline{\text { Signati investigate Principal la }}$ Date 


\section{APPENDIX B}

\section{Exercise of Self-Care Agency Scale (Kearney \& Fleischer, 1979)}

\section{Code Number:}

Directions: This is not a test with right or wrong answers. It is an instrument which helps you assess yourself in terms of the degree in which you take care of your health needs. You will be given a statement, and five possible choices with a letter for each choice. Please write the letter for your choice after each statement.
A
B C somewhat no
very
D $\quad E$ characteristic characteristic opinion somewhat very uncharacteristic uncharacteristic

1. I would gladly give up some of my set ways if it meant improving my health.

2. I like myself.

3. I often feel that I lack the energy to care for health needs the way I would like to.

4. I know how to get the facts I need when my health feels weakened.

5. I take pride in doing the things I need to do in order to remain healthy.

6. I tend to neglect my personal needs.

7. I know my strong and weak points.

8. I seek help when unable to care for myself.

9. I enjoy starting new projects.

10. I often put off doing things that I know would be good for me.

11. I usually try home remedies that have worked in the past rather than going to see a nurse or doctor for help.

12. I make my own decisions. 
13. I perform certain activities to keep from getting sick.

14. I strive to better myself.

15. I eat a balanced diet.

16. I complain a lot about things that bother me without doing much about them.

17. I look for better ways to look after my health.

18. I expect to reach my peak wellness.

19. When I have a problem, I usually want an expert to tell me what to do.

20. I deserve all the time and care it takes to maintain my health.

21. I follow through on my decisions.

22. I have no interest in learning about my body and how it functions.

23. If I am not good to myself, I believe I cannot be good for anyone else.

24. I understand my body and how it functions.

25. I rarely carry out the resolutions I make concerning my health.

26. I am a good friend to myself.

27. I take good care of myself.

28. Health promotion is a chance thing for me.

29. I have a planned program for rest and exercise.

30. I am interested in learning about various disease processes and how they affect me.

31. Life is a joy.

32. I do not contribute to my family's functioning. 
33. I take responsibility for my own actions.

34. I have little to contribute to others.

35. I can usually tell that I am coming down with something days before I get sick.

36. Over the years I have noticed the things to do that make me feel better.

37. I know what foods to eat and keep me healthy.

38. I am interested in learning all that I can about my body and the way it functions.

39. Sometimes when I feel sick I ignore the feeling and hope it goes away.

40. I seek information to care for myself.

41. I feel I am a valuable member of my family.

42. I remember when I had my last health check and return on time for my next one.

43. I understand myself and my needs pretty well. 


\section{APENDICE B}

Exercise of Self-Care Agency Scale (Kearney \& Fleischer, 1979)

Codigo Numerico:

Instrucciones: Esto no es un examen. No existen respuestas correctas a incorrectas. Esto es solo un instrumento que le ayudara a evualar el grado de cuidado que usted toma para cuidar su salud y sus necesidades personales le daremos una frase en la cual existen cinco posibilidades a escojer. Por favor marque su respuesta con la letra que corresponda a cada frase.

A

B

C

D E

siempre

$\begin{array}{ll}\text { muy } & \text { no } \\ \text { frecuente } & \text { opinion }\end{array}$

menos

raro

frecuente

1. Yo cambiaria mi manera de ser si mi salud mejorara.

2. Me gusto a mi mismo.

3. Frecuentemente me siento con falta de energia para cuidar mi salud.

4. Yo se obtener la informacion que necesito cuando mi salud esta comprometida.

5. Me siento orgulloso(o) de las cosas que yo hago para mantenerme saludable.

6. Tiendo a no cuidar mis necesidades personales.

7. Reconozco cuales son mis puntos fuertes y mis puntos debiles.

8. Yo busco ayuda cuando no me puedo atender a mi mismo(a).

9. Me gusta empezar nuevos proyectos.

10. Yo tiendo a demorar cosas que se que son buenas para mi.

11. Yo uso remedios caseros que han sido efectivos anteriormente en vez de 
solicitar ayuda de el medico o enfermera.

12. Yo hago mis propias decisiones.

13. Yo hago ciertas actividades para prevenir enfermarme.

14. Yo me esmero en superarme.

15. Yo como una dieta balanceada.

16. Yo suelo quejarme mucho de cosas que me molestan, pero no hago nada para mejorarlas.

17. Yo quiero buscar mejores maneras de atender mi salud.

18. Yo aspiro a llegar a mi mas alto bienestar.

19. Cuando yo tengo un problema, yo normalmente quiero que un experto me diga que debo hacer.

20. Yo me merezco todo el tiempo y cuidado que toma mantener mi salud.

21. Yo mantengo mis decisiones.

22. Yo no tengo interes en aprender sobre mi cuerpo y sus funciones.

23. Si yo no soy bueno con mi mismo, no puedo ser bueno con los demas.

24. Yo entiendo mi cuerpo y sus funciones.

25. Yo raramente completo las resoluciones que hago sobre mi salud.

26. Yo soy un buen amigo para mi mismo.

27. Yo me cuido bien.

28. La promocion de la salud es una cosa casual para mi.

29. Yo tengo un programa planeado de descanso y ejercicio. 
30. Yo estoy interesado en aprender acerca de varias enfermedades y como me afectan.

31. La vida es un placer.

32. Yo no contribuyo en la funcion de mi familia.

33. Yo tomo responsabilidad por mis propias acciones.

34. Tengo poco que contribuir a otros.

35. Usualmente puedo sentir con anticipacion cuando me voy a enfermar sufrir alguna enfermedad.

36. A travez de los anos he notado que cosas debo hacer para sentirme mejor.

37. Yo se cuales son las comidas que me mantienen saludable.

38. Yo estoy interesado en aprender todo lo que pueda sobre mi cuerpo y su funcionamiento.

39. A veces cuando me siento mal, ignoro mis sintomas y espero a que se me pase.

40. Yo busco informacion sobre como cuidarme mejor.

41. Yo soy un miembro valioso de mi familia.

42. Yo recuerdo cuando fue mi ultima visita medica, y regreso puntualmente a mi proxima visita.

43. Yo me entiendo a mi mismo y se cuales son mis necesidades. 


\section{APENDIX B}

\section{Exercise of Self-care Agency Scale (Kearney and Fleischer, 1979).}

1. Mwen ta kontan jete kek abitid ke-m genyen si sa ap pemet sante-m ameliore.

2. Mwen renmen tet mwen.

3. Tre souvan mwen santi ke-m manke eneji pou-m pran swen bezwen sante nan fason ke-m ta vle.

4. Mwen konnen ki jan pou'm cheche infomatyon pou sante.

5. Mwen genyen-anpil fiete le mwen fe bagay ki pou pemet mwen rete an sante.

6. Mwen gen tandans neglige bezwen pesonel mwen.

7. Mwen konnen poin fo ak poin feb mwen.

8. Mwen cheche aid le-m santi' m pa ka pran swen tet-mwen.

9. Mwen renmen komanse travay sou proje nef.

10. Souvan mwen neglige fe bagay ke-m konnen ki kab bon pou mwen.

11. Mwen renmen esaye remed fey ke-m konnen ki konn bamm soulagman nan tan avan, olie ke-m ale we infimie oswa docte.

12. Mwen pran pwop decisyon-mwen.

13. Mwen pefome kek aktivite ki ka anpeche-m tonbe malad.

14. Mwen goumen pou'm kenbe ko-m en fo-m. 
15. Mwen manje yon diet ki balance.

16. Mwen plenyen anpil le-m gen bagay ki pa fe-m plezi, men mwen pa fe anyen pou'm elimine yo.

17. Mwen cheche moyen ki pi bon pou'm ka pran swen sante-m.

18. Mwen ta renmen rive nan poin ki pi ro a nan fason ke sante-m dwe ye a.

19. Le-m genyen yon pwoblem, mwen toujou rele yon especialis ki pou dimwen sa pou'm fe.

20. Mwen dwe jwenn tout tan ak swen ke mwen merite pou'm ka rete an sante (pou'm ka kimbe sante-m).

21. Mwen toujou tcheke sou decisyon ke-m pran.

22. Mwen pa gen okenn anvi pou'm aprann tout pati nam ko-m ak kijan ke yo konstri.

23. Si-m pa bon ak tet mwen, mwen kwe ke-m pa ka bon pou lot moun.

24. Mwen konprann ko-m, ni jan li constry.

25. Ce rareman mwen fe sa mwem di map fe, pou sante-m.

26. Mwen se yon bonzanmi tet mwen.

27. Mwen pran swen tet mwen.

28. Promotyon sante se yon chans pou mwen.

29. Mwen genyen yon pwogram byen planifye pou-m fe ekzesis et pou-m ka repoze. 
30. Mwen enterese pou-m aprann enfomatyon sou plizie maladi esoujan yo ka afek te-m.

31. Lavi se yon gwa.

32. Mwen pa kontribie nan funktyon man fanmi-m.

33. Mwen pran responsabilite pou aktyon ke mwen komet.

34. Mwen pa gen anpil bagay pou-m kontribie a lot moun.

35. Mwen toujou konnen le ke-m pral tonbe malad kelke jou avan.

36. Apre kelke ane finalman, mwen vin konnen anpil bagay pou-m fe ki ka fe-m ale mye.

37. Mwen konnen ki manje pou-m manje ki pou kenbe-m an sante.

38. Mwen enterese aprann tout sa-m kapab de kom ejan li functyone.

39. Parfwa, le-m santi-m malad, mwen ignore sansation an ak esppwa ke li ap pase.

40. Mwen cheche pran enfomasyon pou-m ka pran swen tet mwen.

41. Mwen sante ke-m se yon memb valab fanmi-m.

42. Mwen songe le-m te fe de nie consiltatyon general mwen e'm te retounin a le pou lot ki te vini apre-la.

43. Mwen konprann tet mwen ak tout bezwen-m tre byen. 


\section{APPENDIX C}

DIABETIC PATIENTS' HEALTH BELIEFS SCALES (Given, Given, Gallin, and Condon, 1983)

\section{Code Number:}

Directions: You will be given a statement, and you have five possible choices with a letter for each choice. After each statement, please write the letter of the choice that most closely matches your beliefs.

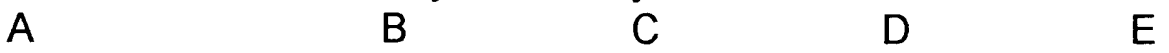

Strongly agree Agree Undecided Disagree Strongly disagree

1. My diabetes is well controlled.

2. My diabetes will have a bad effect on my future health.

3. My diabetes will cause me to be sick a lot.

4. I believe that I can control my diabetes.

5. Following my diet does not interfere with my normal daily activities.

6. I would have to change too many habits to follow my diet.

7. It has been difficult following the diet prescribed for me.

8. I have time to follow the diet the doctor ordered for me.

9. I have others around me who remind me to eat the right foods.

10. I can count on my family when I need help following my diet.

11. My husband/wife helps me to follow my diet.

12. My personal life does not interfere with my diet.

13. I believe that my diet will help prevent diseases (complications) related to diabetes. 
14. Following a prescribed diet is something a person must do no matter how hard it is.

15. I believe that my diet will control my diabetes.

16. I must follow my diet that even if I don't think I am getting better.

17. In general I believe that my diet for diabetes will help me to feel better.

18. I have no one to help me control my weight.

19. Controlling weight is something one must do no matter how hard it is.

20. * If I changed "jobs" it would be easier to follow my diet.

21. $\quad$ My work makes me so tired that it's hard to follow my diet.

22. * I could control my weight if the pressures of my job weren't so great.

23. ${ }^{*}$ It has been difficult to follow work habits prescribed.

24. I am confused by all the medication the doctor has given me.

25. I would have to change too many habits to take my medication.

26. I am not interested in taking my medication regularly.

27. Taking my medication interferes with my normal daily activities.

28. I believe that my medications will help prevent diseases (complications) related to diabetes.

29. Taking medication is something one must do no matter how hard it is.

30. I believe that my medication will control my diabetes.

31. I must take my diabetes medication even if I don't think I am getting better. 
32. I believe that my medication for diabetes will help me to feel better.

33.* If I changed "jobs" it would be easier to take my medication.

34. ${ }^{*}$ My job does not interfere with taking my medication.

35. * I worry so much about my job that I can't take my medication.

Note: Questions with an asterisk* were deleted from analysis since most subjects did not work outside the home. 


\section{APENDICE C}

\section{Codigo Numerico:}

Instrucciones: Le daran una frase que tiene cinco posibilidades de respuesta. Despues de cada frase ponga la letra que le corresponde a su respuesta.

A

Muy de Acuerdo
B

De Acuerdo
C

Indeciso
D

En Desacuerdo
E

Muy en desacuerdo

1. Mi diabetes esta bien controlada.

2. Mi diabetes va a tener un efecto malo para mi salud en el futuro.

3. Mi diabetes me causara estar enfermo(a) a menudo.

4. Yo creo que puedo controlar mi diabetes.

5. El mantener mi dieta no interfiere con mis activadades cotidianas.

6. Tendria que cambiar muchos habitos para poder mantener mi dieta.

7. Ha sido dificil mantener la dieta que me han recomendado.

8. Yo tengo tiempo para mantener la dieta que el medico me a mandado.

9. Tengo personas a mi alrededor que me recuerdan que coma las comidas apropiadas.

10. Puedo contar con mi familia cuando necesito ayuda para mantener mi dieta.

11. Mi esposa/esposo me ayuda a mantener mi dieta.

12. Mi vida personal no interfiere con mi dieta.

13. Yo creo que mi dieta me va a ayudar a prevenir enfermedades (complicaciones) relacionadas con mi diabetes.

14. Seguir una dieta recomendada es algo que uno debe hacer aunque sea 
un poco dificil.

15. Yo creo que mi dieta va a controlar mi diabetes.

16. Tengo que mantener mi dieta aunque crea que no me este mejorando.

17. En general creo que la dieta para mi diabetes me va ayudar a sentirme mejor.

18. No tengo a nadie que me ayude a controlar mi peso.

19. Controlar el peso es algo que hay que hacer aunque sea dificil.

20.* Si yo cambiara de trabajo seria mas facil mantener mi dieta.

21. Mi trabajo me cansa tanto que es dificil mantener mi dieta.

22. * Yo pudiera controlar mi peso si las presiones de mi trabajo no fueran tan grandes.

23. * A sido dificil mantener los habitos de trabajo recomendado.

24. Estoy confudido con todas las medicinas que el medico me ha dado.

25. Tendria que cambiar demasiados habitos para tomar mis medicinas.

26. No estoy interesado en tomar mis medicamentos regularmente.

27. Mis medicamientos interfieren con mis actividades cotidianas.

28. Yo creo que mis medicinas me ayudaran a prevenir complicaciones de mi diabetes.

29. Tomar medicamentos es algo que hay que hacer aunque sea dificil.

30. Yo creo que mis medicamentos me van a controlar mi diabetes.

31. Tengo que tomar mi medicina para la diabetes aunque crea que no me 
esten mejorando.

32. Yo creo que mi medicina para la diabetes me va a ayudar a sentirme mejor.

33. * Si yo cambiara de trabajo seria mas facil tomar mis medicinas.

34. ${ }^{*}$ Mi trabajo no interfiere con mis medicamentos.

35. * Yo me preocupo tanto por mi trabajo que no puedo tomar mis medicinas.

Note: Questions with an asterisk ${ }^{*}$ were deleted from analysis since most subjects did not work outside the home. 


\section{APENDIX C}

\section{Balance sou kroyans la sante malad ki fe suk.}

\section{Numero Cod la:}

Mach a suio: Yo bral ba ou yon fraz e yap ba ou 5 choua possis avek yon let pou chak choua. Apre chak fraz ekri let pou choua ki plis mache avek kroyans ou sou ple.
A
B
C
D $\quad$ E
Mouin
Mouin
Mouin
Mouin
Mouin
tre dako
pa ka decide
pa dako reelman pa dako

1. Maladi suk mouin an bien controle.

2. Maladi suk moin an ap ginyin yon movez efe sou sante mouin demin.

3. Maladi suk mouin an ap fe mwem malad anpil.

4. Moin koye mouin ka controle maladi suk mouin an.

5. Suiv diet mouin pa kabak empeche mouin fe sa mouin vole fe pou jounin an.

6. Fo mouin ta change anpil abitid pou'm ta ka suiv diet mouin yan/

7. Li tre difficil pou mouin suiv diet yo prescri mouin an.

8. Mouin gin tan pou'm suiv diet dokte a prescri mouin an.

9. Mouin gin lot mouin avek mouin ki fe mouin sonje pou mouin manje manje ki bon pou mouin.

10. Mouin ka konte sou fanmi mouin le mouin besoin aid pou mouin suiv diet mouin an.

11. Mari mouin ou bien madam mouin ede mouin suiv diet mouin.

12. Vi prive mouin pa ampeche mouin suiv diet mouin. 
13. Mouin kone ke diet mouin ap ede evite lot maladi ki gin rapo avek maladi suk.

14. Suiv diet ke yo prescri ou la se yon bagay ke ou doue fe kelke souv jan li di a.

15. Mouin ke diet mouin an ap kontrole maladi suk mouin an.

16. Mouin suppose suiv diet mouin mim si mouin ta konnin mouin pap gaya.

17. Generalman mouin kone ke diet pou maladi suk la pral ede mouin pou mouin santi'm mie.

18. Mouin pa gin peson pou ede mouin controle poua mouin.

19. Kontrole poua ou se yon bagay ke mouin done fe mim si li di.

20. ${ }^{\star}$ Si'm chanje travay lap pi facil pon mouin suiv diet mouin an.

21. * Travay mouin an fe mouin telman fatigue ke li di pon mouin suiv diet mouin an.

22. $\quad$ M'ta ka kontrole poua mouin si mouin pat ginyin tout pression sa yo nan travay mouin.

23. * Li tre dificil pou'm suiv abitid yo mande'm pou'm travay.

24. Mouin pa ka suiv tout medikamen dokte a prescri'm.

25. Fo'm ta change tout abitid mouin ginyin pou'm ta pran medikaman'm.

26. Mouin pa interese pran medikaman mouin chak jou.

27. Le'm pran medikaman mouin li kontraye jounin an.

28. Mouinb koue ke medikamman ke m'ap pran ap ede mouin evite lot maladi 
ki gin rapo ak maladi suk.

29. Pran medikaman se yon bagay ke ou k-ap fe mim si li di.

30. Mouin koue ke medikaman ap ede kontrole maladi suk la.

31. Mouin oblige pran medikamen pou suk la mim si mouin tu konnin li pap fe'm gaya.

32. Mouin koue ke medikaman pou maladi suk pral ede santi'm miyo.

33. ' Si'm change travay mouin an lap vin pi facil pou'm pran medikamam-an.

34. * Travay mouin pa empeche'm pran medikaman an.

35. * Li telman travay mouin an boulvese'm mouin pu fonti pran medikaman'm.

Note: Questions with an asterisk ${ }^{\star}$ were deleted from analysis since most subjects did not work outside the home. 


\section{APPENDIX D \\ DEMOGRAPHIC DATA SHEET}

\section{Code Number:}

Please complete the following information:

1. Date of Birth

2. Sex (Select one)

Female __ Male

3. Highest Educational Attainment (Select one)

Grade School

High School

Associate Degree

Baccalaureate degree

Graduate Degree

4. Marital Status (Select one)

Single

Divorced

$\longrightarrow$

Widowed

5. Ethnic Group (select one)

Black non-Hispanic

White non-Hispanic

Hispanic
Married

Separated 
Asian/Pacific Islander

Native American

Other (specify)

6. Income Level (Select one)

$\begin{aligned} \$ 0-10,000 & - \\ \$ 10,001-19,999 & - \\ \$ 20,000-29,999 & - \\ \$ 30,000-39,999 & - \\ \$ 40,000-49,999 & \\ \$ 50,000 \text { or more } & \end{aligned}$

7. When were you diagnosed as a diabetic? (Choose one)

Less than 1 year ago

1 - 2 years ago

$3-5$ years ago

6 - 8 years ago

$8-10$ years ago

More than 10 years ago

8. Do you live alone? Yes

No

If yes, how long?

9. Do you have someone to help you at home?

Yes

No 


\section{APENDICE D}

\section{DATA DEMOGRAFICA}

\section{Codigo Numerico:}

Por favor complete la siguiente informacion:

1. Fecha de nacimiento

2. Sexo (Escoja uno)

Femenino

Masculino

3. Nivel de Educacion mas alto (Escoja uno)

Primaria

Secundaria

Bachillerato

Universidad (2 anos)

Universidad (>4 anos)

4. Estado Civil (Escoja uno)

Soltero(a)

Divorciado(a)

Casado(a)

Viudo(a)

Separado(a)

5. Grupo Etnico (Escoja uno)

Negro no-hispano

Hispano

Blanco no-hispano

Asiatico

Americano Nativo

Otro (especifique) 
6. Nivel de Ingresos (Escoja uno)

$\begin{aligned} \$ 0-10,000 & - \\ \$ 10,000-19,999 & - \\ \$ 20,000-29,999 & - \\ \$ 30,000-39,999 & \\ \$ 40,000-49,999 & \\ \$ 50,000 \text { o mas } & \end{aligned}$

7. Cuando fue diagnosticado con diabetes (Escoja uno)

Menos de un ano

$1-2$ anos

$3-5$ anos

$6-8$ anos

$8-10$ anos

mas de 10 anos

8. Usted vive solo? Si

No

Si vive solo, hace cuanto tiempo?

9. Tiene a alguien que lo ayude en la casa?

Si

No 


\section{APPENDIX D \\ DEMOGRAPHIC DATA}

\section{Numero Cod la:}

S'il vou plait founi infomacion sa yo:

1. Dat ou fet

2. Es que ou se yon fi ou byen ou gason.

3. Ki pi gro klas ou fe

Elemantary

Secondair

Es ce que ou gen degre

Es ce que ou gen degre baccaloreat

4. Es ce que ou marie divoce separe

Es ce que mari ou ou bye madam ou mouri

5. Es ce que ou nwa

pangnol

blan

Mouin ki fet an Azi ou bien nan Zantille Pacifik

Indien ki fet an Amerik

Lot group (specifie) 
6. Sote pa ane (chouzi youn)

$$
0-10.000 \text { dolla }
$$

10.001-19,999 dolla

$20.000-29,999$ dolla

$30.000-39.999$ dolla

$40,000-49,999$ dolla

50,000 ou bien pliss

7. Depi ki le yo decouvri ke on fe maladi suk (chouazi youn)

Moins ke youn ane

1 - 2 anne de sa

3 - 5 anne de sa

6 - 8 anne de sa

8 - 10 anne de sa

Pliss ke 10 anne de sa

8. Eske ou rete pou kon't ou?

Oui

Non

Si se oui, konbien tan?

9. Eske ou gin moun pou ede ou lakay ou?

Oui

Non 


\section{APPENDIX E}

\section{METABOLIC CONTROL PROFILE-- DATA COLLECTION SHEET}

\begin{tabular}{|c|c|c|c|c|c|c|}
\hline Code No. & FBS \#1 & FBS \#2 & FBS \#3 & $\begin{array}{l}\text { GlyHgb } \\
\# 1\end{array}$ & $\begin{array}{l}\text { GlyHgb } \\
\# 2\end{array}$ & $\begin{array}{l}\text { GlyHgb } \\
\# 3\end{array}$ \\
\hline & & & & & & \\
\hline & & & & & & \\
\hline & & & & & & \\
\hline & & & & & & \\
\hline & & & & & & \\
\hline & & & & & & \\
\hline & & & & & & \\
\hline & & & & & & \\
\hline & & & & & & \\
\hline & & & & & & \\
\hline & & & & & & \\
\hline & & & & & & \\
\hline & & & & & & \\
\hline & & & & & & \\
\hline . & & & & & & \\
\hline
\end{tabular}

Legend: FBS = fasting blood sugar \#1,\#2,\#3 are the three most recent values. $\mathrm{GlyHgb}=$ glycosylated hemoglobin \#1,\#2, \#3 are the three most recent values. 


\section{APPENDIX F}

\section{PERMISSIONS}




\section{INSTITUTIONAL REVIEW BOARD \\ APPROVAL FORM \\ FLORIDA INTERNATIONAL UNIVERSITY \\ University Park Campus \\ Miami, Florida 33199}

This is to certify that the program listed below has been reviewed and approved by the Institutional Review Board (IRB) in accordance with the requirements of 45 CFR 46, including its relevant status.

Principal Investigator/ Project Director: Sonia Anglin

Title of Application: An Investigation of the Relationships among Self-Care Behaviors, Health Beliefs and Metabolic Control in the Non-Insulin-Dependent Diabetic Adult.

Agency Submitted to:

Proposal Identification Number (if available):

\section{Certificate of IRB:}

June 20, 1996 - Date of IRB Review and Approval/Disapproval Full Board Review X_ Expedited Review

Comments:

Full approval.

Any problems should be immediately brought to the attention of the IRB Council.

The official signing below certifies that the information provided on this form is correct and the institution assumes responsibility for assuring future reviews, approvals, and submissions of certification.

Luz Porter, Member

University Research Council

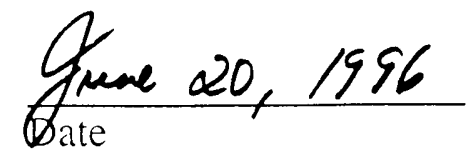

IRB FORM 09/91 [ma] 


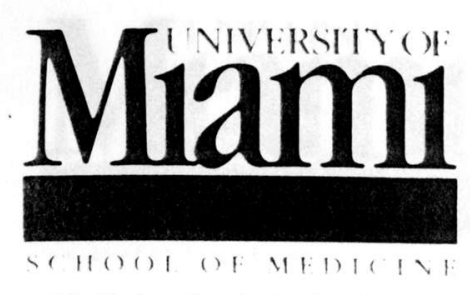

\section{MEMORANDUM}

TO: Jay Sosenko, M.D., Medicine Sonia Anglin, RN

FROM:

Maria J. Arnold

IRB Administrator

DATE:

February 2, 1996

PROTOCOL NUMBER: $\quad 96 / 08$

TITLE OF PROTOCOL: "An Investigation of the Relationship Among Self-Care Behaviors, Health Beliefs, and Metabolic Control in the NonInsulin-Dependent Diabetic Adult"

DATE OF APPROVAL: January 18, 1996

The Behavioral Sciences Subcommittee for the Protection of Human Subjects in Research reviewed your protocol on January 18, 1996. Approval has been granted for the above titled protocol and consent form.

Please have your subjects sign the consent forms with the IRB stamp of approval. Signed consent forms should be kept on file by the investigator.

Any changes made to the protocol must be submitted to the IRB before it is implemented.

A follow-up report will be required one year from the data of approval, in accordance with Federal Regulations. Appropriate forms will be sent to you in advanced. Notice of termination is required when this study is completed.

If you have any questions, please contact me at 243-3327. 
December 8, 1995

Dr. Barbara Kearney

Associate Professor, School of Nursing

Louisiana State University

New Orleans, LA

\section{Dear Dr. Kearney:}

Thank you for taking the time to speak with me earlier today.

I am a graduate student in the School of Nursing at the Florida International University in Miami, Florida. My thesis topic is "An investigation of the relationship between self-care practices and metabolic control in the non-insulin-dependent diabetic adult." The research subjects would be selected from clinic attenders at a large teaching hospital here in the southeastern United States. I am seeking permission to utilize your instrument "The Exercise of Self-care Agency Scale" to measure the degree of self-care agency in this population of patients.

If you have any questions about this research, please feel free to call me at (954) 4310344. I would be grateful for your kind attention to this request. Thank you.

Sincerely,

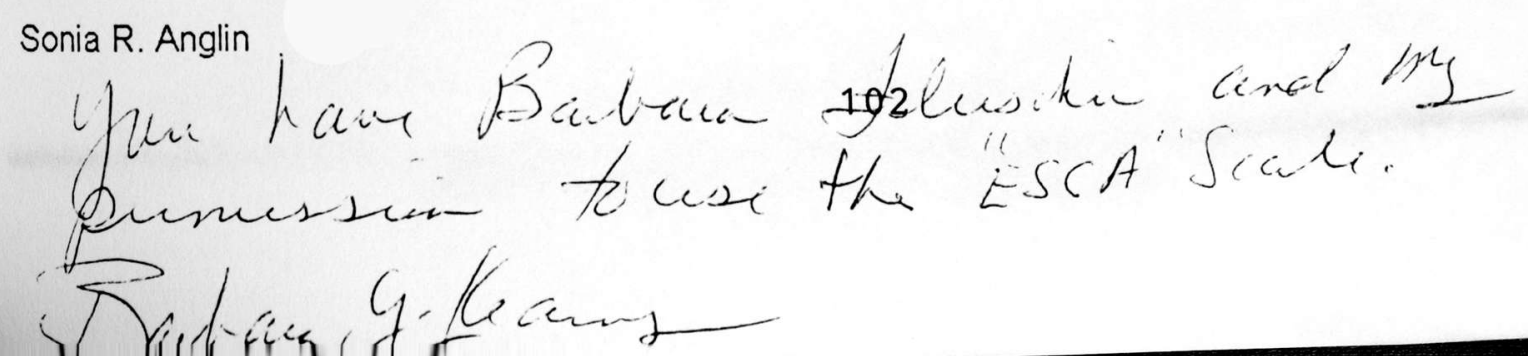




\section{Family Care Study}

Michigan State University

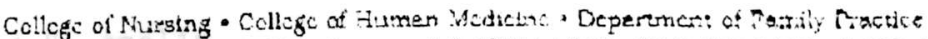

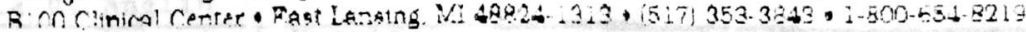

\section{MEMORANDUM}

TO:

Sonia Anglin

FROM:

Danielle DeVoss

DATE:

December 19, 1995

$\mathrm{RE}:$

Permission Request

Permission is granted to reproduce the scales as indicated on the copy of the attached Permission Request Form.

Wo look forware to roceiving a description of your procedures and your results. Good luck with your researchl 


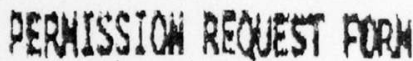 \\ Fanlly Car studia}

Name: Scola R, Aaglin

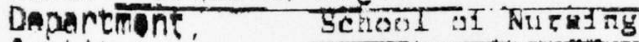

institute,

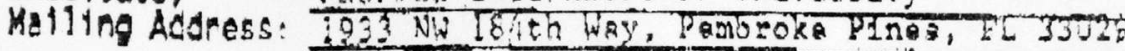

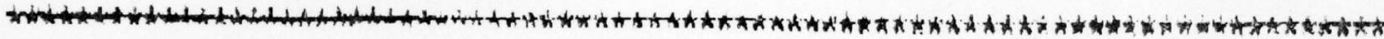
OCSCRIPTION OF RLSEAPCH

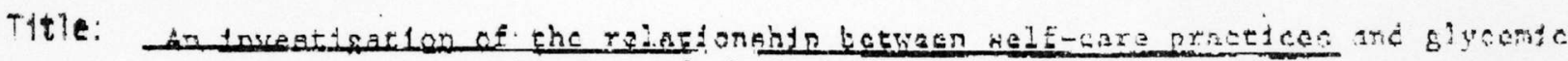

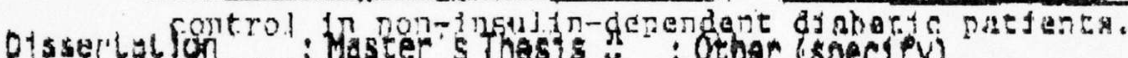

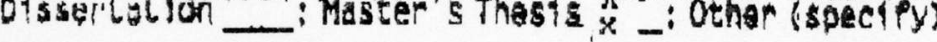

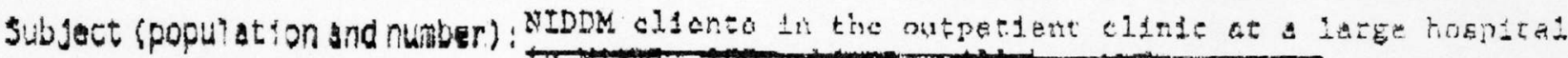

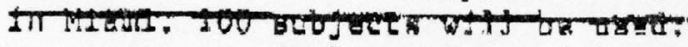

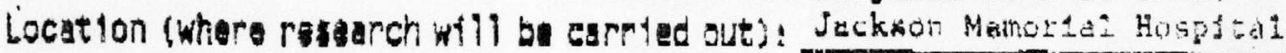

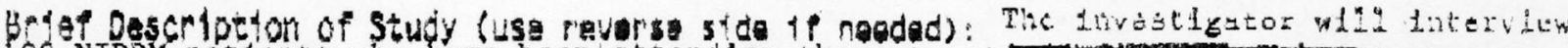

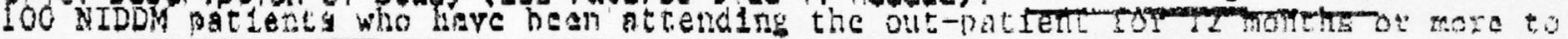

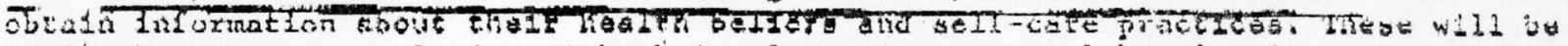
anslyzed for any correlation wath thatr glycusylated hemogiobin levels.

Funded! If YES, Funding Sourea:

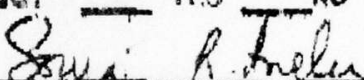

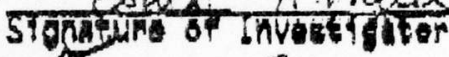

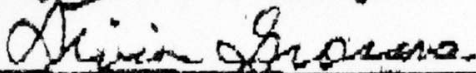

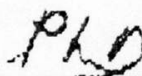

$12 / 11 / 95$

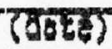

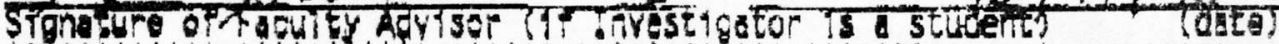

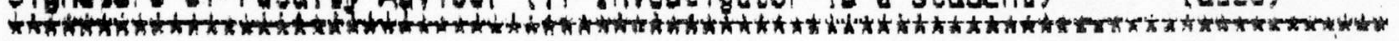

1. Pamigsion is roquestod to reproduce the scai (s) or data roguas indiatsed biow for the reseoreh project thel : have wescribod:

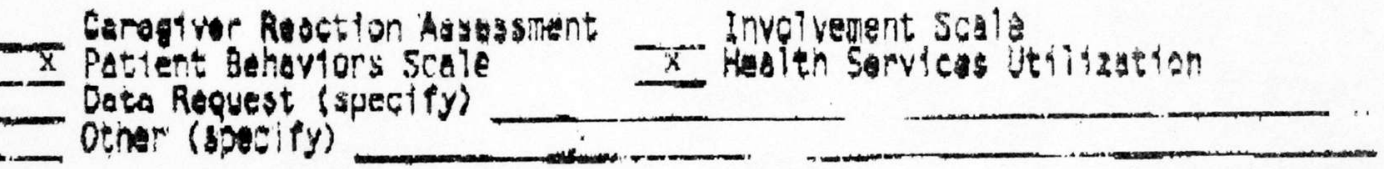

$\therefore$ All dala or geales will bo usac in accordanco with the Code of Ethics of the Anerican Psychologicel Aseociation.

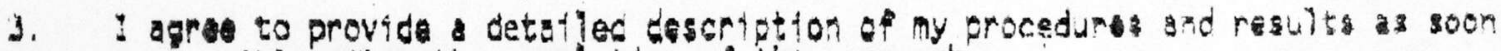
as possible artar the complation of the rosearch.

4. : agres thas wherever doto is presertad in any isshton that the grant t"is.

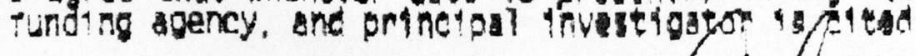

Return comolezed form to: charlos W. Given, Pn. D

pormilssion is grantad.

Michigen Stato Urifyarstty

copartant of Ram ly practico

8.208 ênical Centar

East Lansing. MI $48823 \cdot 1313$

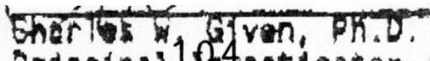

arincipa? Chasestiostor 